\title{
Macroalgal meadow habitats support fish and fisheries in diverse tropical seascapes
}

\author{
Christopher J. Fulton $^{1}$ (D) | Charlotte Berkström ${ }^{2,3}$ (D) | Shaun K. Wilson ${ }^{4,5}$ (D) | \\ Rene A. Abesamis ${ }^{6}$ (D) | Michael Bradley ${ }^{7}$ (D) | Carolina Åkerlund ${ }^{2}$ | Luke T. Barrett ${ }^{8}$ \\ Abner A. Bucol ${ }^{6}$ | Dinorah H. Chacin ${ }^{9}$ | Karen M.Chong-Seng ${ }^{10}$ | Darren J.Coker ${ }^{11}$ | \\ Martial Depczynski ${ }^{4,12}$ (D) | Linda Eggertsen ${ }^{2}$ | Maria Eggertsen ${ }^{2}$ | David Ellis ${ }^{1}$ | \\ Richard D. Evans $^{4,5}$ | Nicholas A. J. Graham ${ }^{13}$ (D) | Andrew S. Hoey ${ }^{10}$ |
} Thomas H. Holmes ${ }^{4,5}$ | Michel Kulbicki ${ }^{14}$ (D) | Priscilla T. Y. Leung ${ }^{15}$ | Paul K. S. Lam ${ }^{15}$ | Joshua van Lier ${ }^{1}$ | Paloma A. Matis ${ }^{16}$ (D) | Mae M. Noble ${ }^{1,17}$ | Alejandro Pérez-Matus ${ }^{18}$ | Camilla Piggott $^{4}$ | Ben T. Radford ${ }^{4,12}$ | Stina Tano ${ }^{2}$ | Paul Tinkler ${ }^{12,19}$

\footnotetext{
${ }^{1}$ Research School of Biology, The Australian National University, Canberra, ACT, Australia

${ }^{2}$ Department of Ecology, Environment \& Plant Sciences, Stockholm University, Stockholm, Sweden

${ }^{3}$ Department of Aquatic Resources, Institute of Coastal Research, Swedish University of Agricultural Sciences, Öregrund, Sweden

${ }^{4}$ Oceans Institute, University of Western Australia, Crawley, WA, Australia

${ }^{5}$ Marine Science Program, Department of Biodiversity, Conservation \& Attractions, Government of Western Australia, Kensington, WA, Australia

${ }^{6}$ Silliman University Angelo King Center for Research and Environmental Management, Dumaguete, Negros Oriental, Philippines

${ }^{7}$ Marine Biology and Aquaculture Unit, College of Science and Engineering, James Cook University, Townsvillem, QLD, Australia

${ }^{8}$ School of BioSciences, University of Melbourne, Parkville, VIC, Australia

${ }^{9}$ College of Marine Science, University of South Florida, St. Petersburg, FL, Australia

${ }^{10}$ Australian Research Council Centre of Excellence for Coral Reef Studies, James Cook University, Townsville, QLD, Australia

${ }^{11}$ Division of Biological, Environmental Sciences and Engineering, King Abdullah University of Science and Technology, Thuwal, Saudi Arabia

${ }^{12}$ Australian Institute of Marine Science, University of Western Australia, Crawley, WA, Australia

${ }^{13}$ Lancaster Environment Centre, Lancaster University, Lancaster, United Kingdom

${ }^{14}$ UMR "Entropie", Labex Corail, IRD, University of Perpignan, Perpignan, France

${ }^{15}$ State Key Laboratory of Marine Pollution, City University of Hong Kong, Hong Kong SAR, China

${ }^{16}$ School of Life Sciences, University of Technology Sydney, Broadway, NSW, Australia

${ }^{17}$ Fenner School of Environmental and Society, The Australian National University, Canberra, ACT, Australia

${ }^{18}$ Subtidal Ecology Laboratory, Estación Costera de Investigaciones Marinas, Departamento de Ecología, Facultad de Ciencias Biológicas, Pontificia Universidad Católica de Chile, Santiago, Chile

${ }^{19}$ School of Life and Environmental Sciences, Deakin University, Warrnambool, VIC, Australia
}

\section{Correspondence}

Christopher J. Fulton, Research School of Biology, The Australian National University, Canberra, ACT 2601, Australia.

Email: christopher.fulton@anu.edu.au

Funding information WA Department of Biodiversity, Conservation \& Attractions; Australian National University; Government of Hong Kong; Philippine Department of Science and Technology; Royal Society, Grant/ Award Number: Fellowship (UF140691);

\begin{abstract}
Canopy-forming macroalgae can construct extensive meadow habitats in tropical seascapes occupied by fishes that span a diversity of taxa, life-history stages and ecological roles. Our synthesis assessed whether these tropical macroalgal habitats have unique fish assemblages, provide fish nurseries and support local fisheries. We also applied a meta-analysis of independent surveys across 23 tropical reef locations in 11 countries to examine how macroalgal canopy condition is related to the abundance of macroalgal-associated fishes. Over 627 fish species were documented in tropical
\end{abstract}


Swedish Research Council, Grant/Award Number: 2015-01257 and E0344801; the Environment Conservation Fund of the Government of Hong Kong SAR, Grant/ Award Number: ECF15/2015; the Australian Research Council, Grant/Award Number: DE130100688 macroalgal meadows, with 218 of these taxa exhibiting higher local abundance within this habitat (cf. nearby coral reef) during at least one life-history stage. Major overlap (40\%-43\%) in local fish species richness among macroalgal and seagrass or coral reef habitats suggest macroalgal meadows may provide an important habitat refuge. Moreover, the prominence of juvenile fishes suggests macroalgal meadows facilitate the triphasic life cycle of many fishes occupying diverse tropical seascapes. Correlations between macroalgal canopy structure and juvenile abundance suggests macroalgal habitat condition can influence levels of replenishment in tropical fish populations, including the majority of macroalgal-associated fishes that are targeted by commercial, subsistence or recreational fisheries. While many macroalgal-associated fishery species are of minor commercial value, their local importance for food and livelihood security can be substantial (e.g. up to $60 \%$ of landings in Kenyan reef fisheries). Given that macroalgal canopy condition can vary substantially with sea temperature, there is a high likelihood that climate change will impact macroalgalassociated fish and fisheries.

\section{KEYWORDS}

coral reef, nursery, ontogenetic migration, recruitment, Sargassum, seagrass

\section{1 | INTRODUCTION}

Conservation and management of fish biodiversity requires an understanding of the habitats needed to support and replenish all of the species in a region of interest. While some species may be uniquely linked to a certain habitat type, many fish taxa follow a triphasic life cycle, where planktonic larvae settle into an initial habitat before migrating to different habitats as juveniles and/or adults. Moreover, adult fishes often move among habitats over daily or longer time scales to fulfil foraging or reproductive activities. Characterization of a fauna according to surveys within a single habitat type, therefore, can lead to a conclusion that a collection of species are dependent on that habitat type. A wider seascape perspective that tracks the abundance and activities of fishes across different patch habitat types is needed to reveal the full suite of connected habitats that sustain fish populations and communities (Brown et al., 2018; Olds et al., 2018; Sambrook et al., 2019).

Tropical seascapes often comprise a mosaic of patch habitats created by corals, seagrass, sponges, mangroves and canopy-forming macroalgae, any of which may be utilized by fishes. Considerable effort has been devoted to understanding the fish-habitat functions performed by some of these patch types, particularly corals (e.g. Coker, Wilson, \& Pratchett, 2014), seagrass (e.g. Gillanders, 2006) and mangroves (e.g. Faunce \& Serafy, 2006). Despite the long-recognized importance of macroalgae for fish and fisheries in temperate waters (Bertocci, Araújo, Oliveira, \& Sousa-Pinto, 2015), comparatively little attention has been directed to how tropical macroalgal habitats may influence patterns of fish diversity, replenishment and fisheries production (Figure 1).

Macroalgal meadows can cover large areas of tropical seascapes (16\%-46\% of shallow waters; Fulton et al., 2019) to provide food and shelter for shallow-water tropical fishes. Typically, these meadows are dominated by canopy-forming macroalgae (e.g. Sargassum,

\begin{tabular}{|c|c|}
\hline 1. INTRODUCTION & 2 \\
\hline $\begin{array}{l}\text { 2. TROPICAL MACROALGAL FISHES: A DISTINCT } \\
\text { ASSEMBLAGE? }\end{array}$ & 3 \\
\hline $\begin{array}{l}\text { 3. TROPICAL MACROALGAL MEADOWS AS FISH } \\
\text { NURSERIES }\end{array}$ & 5 \\
\hline $\begin{array}{l}\text { 4. MACROALGAE-ASSOCIATED TROPICAL } \\
\text { FISHERIES }\end{array}$ & 8 \\
\hline $\begin{array}{l}\text { 5. VULNERABILITY OF MACROALGAL FISHES TO } \\
\text { HABITAT LOSS }\end{array}$ & 10 \\
\hline 6. CONCLUSIONS & 14 \\
\hline ACKNOWLEDGEMENTS & 14 \\
\hline DATA AVAILABILITY & 14 \\
\hline REFERENCES & 14 \\
\hline
\end{tabular}

Sargassopsis, Sirophysalis, Turbinaria) with various understory genera (e.g. Lobophora, Dictyota, Padina) and an abundant epifaunal community, which provides a diverse prey base for higher-order consumers such as fish (Bittick, Clausing, Fong, Scoma, \& Fong, 2019; Fulton et al., 2019; Tano et al., 2016). Indeed, current evidence suggests these complex macroalgal meadows are occupied by diverse assemblages of tropical fishes at various life-history stages (e.g. Chaves, Pereira, \& Feitosa, 2013; Eggertsen, Chacin, Halling, \& Berkström, 2019; Ornellas \& Coutinho, 1998; Rossier \& Kulbicki, 2000), some of which may support local fisheries (e.g. Campos, del Norte-Campos, \& McManus, 1994; Hicks \& McClanahan, 2012; Robinson et al., 2018). Tropical macroalgal meadows, however, are dynamic habitats that can vary dramatically in canopy structure across seasons and years 
FIGURE 1 Cumulative number of published studies on fish community structure within tropical macroalgae meadows (dark bars), and within macroalgae-dominated habitat that arose from a coral-macroalgal regime shift (grey bars). Published research effort on tropical fish communities within two other major macrophyte habitats-seagrass beds (solid line) and mangrove forests (dotted line)-are provided for comparison. Results are for 1985 to 2018 inclusive, based on a Scopus search conducted on 17 March 2019

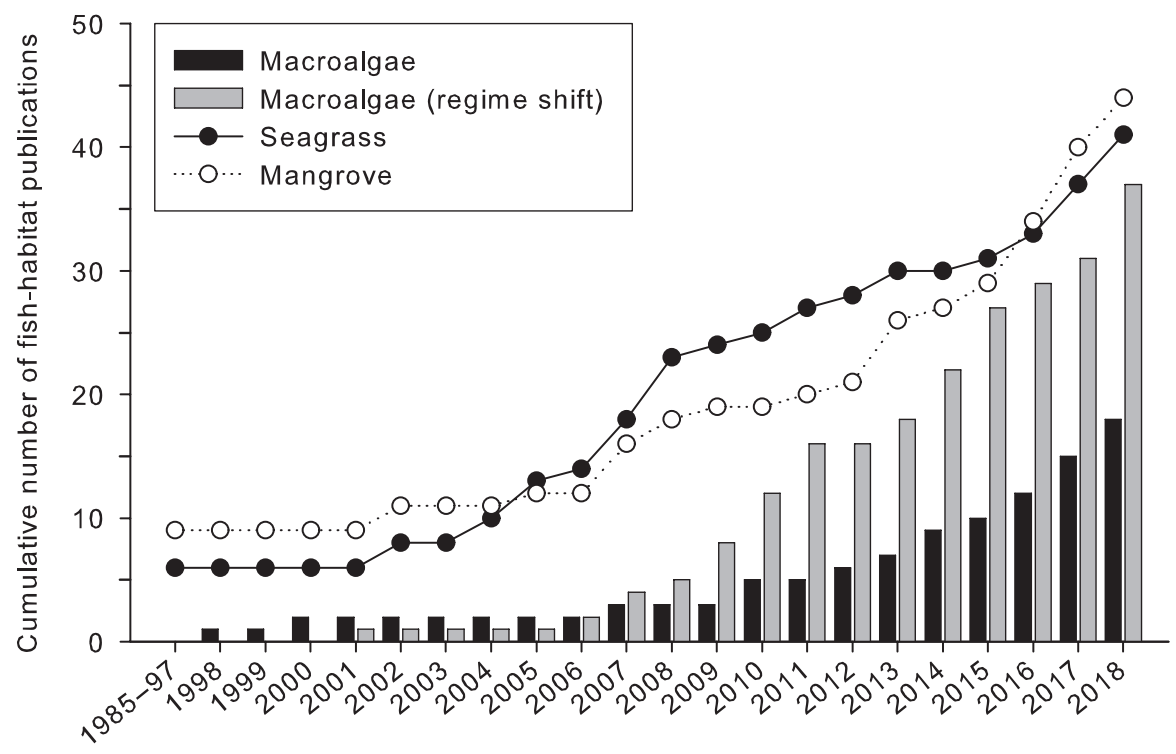

(Fulton et al., 2019). Although individual studies have documented how changes in canopy condition can influence the abundance of certain macroalgae-associated fishes (e.g. Aburto-Oropeza, Sala, Paredes, Mendoza, \& Ballesteros, 2007; Ornellas \& Coutinho, 1998; Wilson et al., 2017), large-scale assessments are needed to understand the generality and nature of these macroalgal habitat effects on patterns of tropical fish diversity, abundance and replenishment.

In this synthesis we assess whether: (a) tropical macroalgal meadows have unique fish assemblages based on overlap in species occurrence and relative abundance with adjacent coral and seagrass habitats (Section 2), (b) macroalgal habitats provide fish nurseries in tropical seascapes (Section 3) and (c) macroalgal-associated species support tropical fisheries (Section 4). We also used a meta-analysis to assess (d) the relationship between macroalgae habitat condition and the abundance of macroalgal-associated tropical fishes (Section 5). To do this, we collated data from 23 independent studies in 11 countries (Figure 2) that conducted underwater visual surveys across at least two adjacent habitat types within a tropical seascape (see Methods in Supporting Information for full details). We define habitats as areas dominated by the biogenic components of canopy-forming macroalgae (macroalgal meadows), live hard corals (coral reef) or seagrass (seagrass beds). Due to data availability, the majority of our analyses focused on independent surveys that recorded the relative abundance of tropical fishes across adjacent areas of macroalgal meadow and coral reef (Table S1). In doing so, we identify how and why macroalgal habitats should be considered in the conservation and management of tropical fish and fisheries, and the emerging research fronts that are needed to bridge key knowledge gaps.

\section{2 | TROPICAL MACROALGAL FISHES: A DISTINCT ASSEMBLAGE?}

Studies exploring fish community structure in tropical macroalgal habitats have steadily increased over the past two decades, yet the majority of such studies have been directed towards the consequences of coral-algal regime shifts (Figure 1). In some respects, this has skewed perspectives towards tropical macroalgae as a "degraded" reef state for fishes in areas where a loss of live coral cover has led to substantial losses of biodiversity (e.g. Feary, Almany, McCormick, \& Jones, 2007; Graham et al., 2006). However, studies that have documented tropical fish assemblages in macroalgal meadows co-occurring alongside patches of coral reef and seagrass provide a different seascape perspective. Drawing on results from 14 independent studies that deployed comparable levels of visual survey effort across macroalgal meadows and two other tropical habitats (coral and/or seagrass, Table S2), we found the average proportion of local fish species richness that was only found within tropical macroalgal habitats was low (18\%) relative to nearby coral reef (39\%). However, we found the reverse for fish species found only in macroalgal meadows (40\%) versus only in seagrass beds (20\%). This suggests a sizeable portion of tropical fish biodiversity occupying macrophyte habitats are unique to macroalgal meadows, and that seagrass and macroalgae are not interchangeable habitats for the ecological connectivity of many macrophyte-associated fishes. Moreover, we found an average of $43 \%$ and $40 \%$ amonghabitat overlap in local fish species among tropical macroalgaecoral and macroalgae-seagrass habitats, respectively (Figure 3). In some locations, this overlap was as high as $60 \%-80 \%$ (e.g. Ningaloo, Seychelles; Table S2). Since over a third of fish species within a region can occupy both macroalgal and coral habitats, macroalgal meadows could provide stepping stones or refuge habitats for fishes occupying a diverse tropical seascape subject to disturbance events. Depending on the trophic diversity of these macroalgal-associated fishes, such overlaps in habitat occupation could help stabilize ecosystem structure and function in the face of disturbances affecting a particular habitat type (e.g. mass-bleaching of corals).

Our compilation of fishes detected in tropical macroalgal meadows by 23 independent surveys (Table S1) found a broad range of taxonomic diversity, with 627 bony fish species from 75 families 


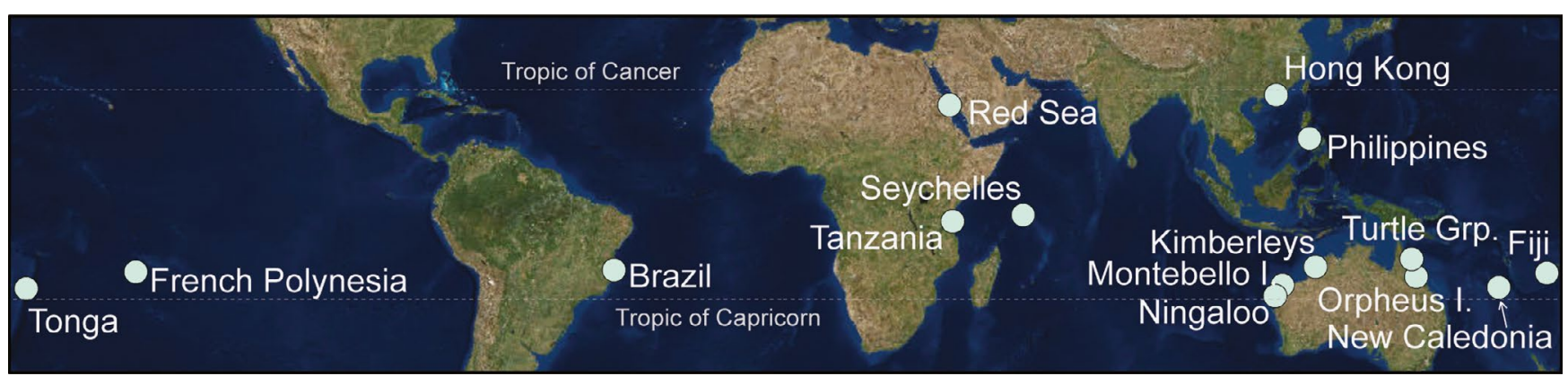

FIGURE 2 Location of the 24 independent studies (with some geographic overlap) included in different aspects of our data syntheses and meta-analysis of macroalgal-associated tropical fishes (see Table S1). Note figure appears in colour in the online version only

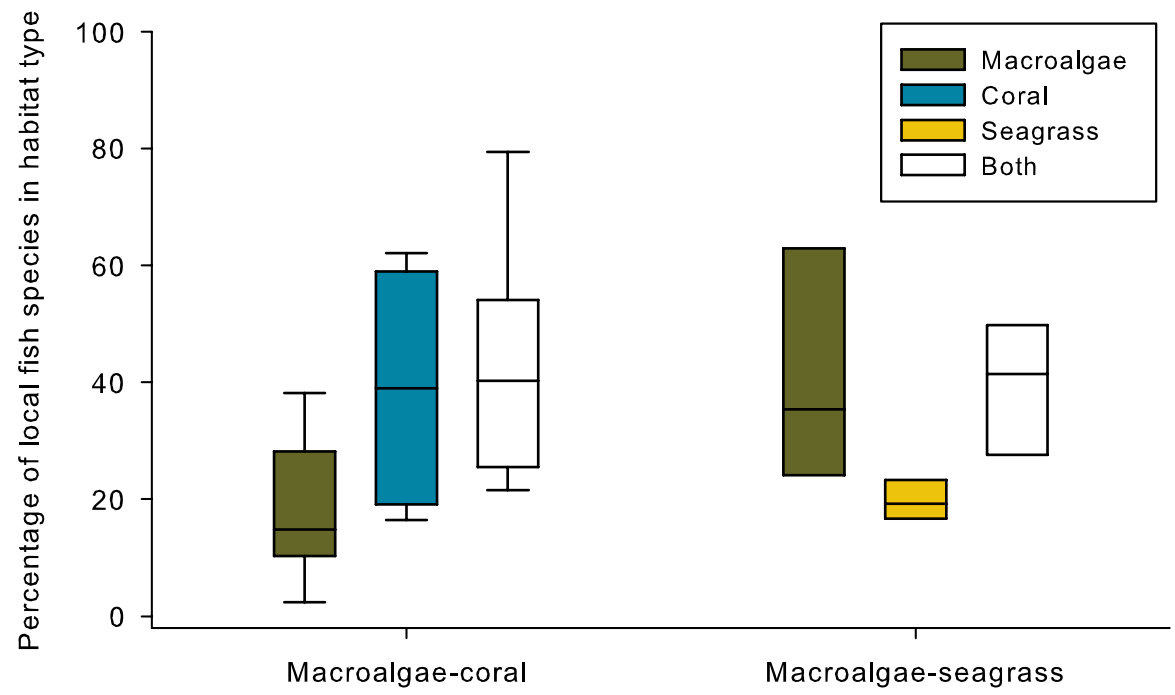

FIGURE 3 Percentage of conspicuous fish species (readily detected by visual surveys) occupying only tropical macroalgae, coral reef or seagrass habitats, or occurring in both habitat types based on studies that explored pairwise (macroalgae versus coral/seagrass) occupation patterns. Boxplots indicate number of fish species that fall into each category, expressed as a percentage of the total fish species recorded in each of 12 (macroalgae-coral) and 7 (macroalgae-seagrass) independent studies encompassing 7 or more tropical locations (underlying data in Table S2). Note figure appears in colour in the online version only

occurring as a juvenile and/or adult at some level of abundance (Table S3). At least some evidence suggests that a third of these macroalgal-associated fishes (218 species) had most (more than half) of their local abundance within macroalgal habitats, either as juveniles (147 species) or adults (130 species; Table S3). Taking a smaller subset of species for which we had replicated surveys (at least $n=2$ for both life-history stages) of relative abundance, we identified 44 fish species as being most strongly macroalgae-associated because one or both life-history stages were predominantly abundant in macroalgal meadows compared to nearby coral reef (Figure 4). Focusing on the 35 species with more than half of their adults within macroalgae, which we call macroalgal residents, we find a diversity of trophic levels and groups, from herbivores and detritivores (e.g. Marbled parrotfish, Leptoscarus vaigiensis, Labridae; and some Siganus species), to omnivores (Chrysiptera species) and benthic invertivores (e.g. some Coris, Choerodon, Halichoeres, Pseudojuloides, Pteragogus, Stethojulis and Lethrinus species). A relatively small component of this macroalgal resident fish fauna (9\%) are higher trophic level carnivores that are known to consume other fishes (e.g. Cigar wrasse, Cheilio inermis, Labridae; Starry moray, Echidna nebulosa, Muraenidae; Halfmoon grouper, Epinephelus rivulatus, Serranidae; and Bluespotted cornetfish, Fistularia commersonii, Fistularidae). A larger group of fishes (78 species) also had a substantial proportion (between a quarter to a half) of their relative adult abundance within tropical macroalgal habitats. This lower relative abundance may reflect a more opportunistic or transient occupation of macroalgae, where these fishes could be exploiting a range of trophic resources, given they span herbivores and detritivores (Acanthurus, Chlorurus, Scarus and Siganus species), to omnivores (Common silver-biddy, Gerres oyena, Gerreidae), generalist carnivores (e.g. some Lethrinus, Lutjanus, Thalassoma and Mullidae species) and fishes (8\% of 77 species) known to consume other fishes (e.g. some Caranx, Gymnothorax, Pterois, Saurida and Synodus species; Figure 4, Table S3). Notably, the mean trophic level of these resident (3.21, 35 species) and opportunistic (3.18, 78 species) fish groups are relatively similar. A typical adult fish found in tropical macroalgal habitat appears to be targeting invertebrate 
FIGURE 4 Proportional abundance of juveniles and adults for 350 fish species within macroalgal habitat relative to nearby coral reef, classified according to their adult trophic level (2.002.99 = white circles; 3.00-3.99 = grey; 4.00 or greater $=$ black). Outer quadrants indicate species with higher macroalgal dependency due to majority (over half) of their juveniles (blue, 9 species, median trophic level $=3.68$ ), adults (yellow, 13 species, 3.50), or both stages (green, 22 species, 3.50) occupying macroalgal habitats (Table S3). An additional 13 species had an equal proportion (0.5) of one or both life-history stages among habitats (i.e. fall on the boundary lines of the quadrants). Note figure appears in colour in the online version only

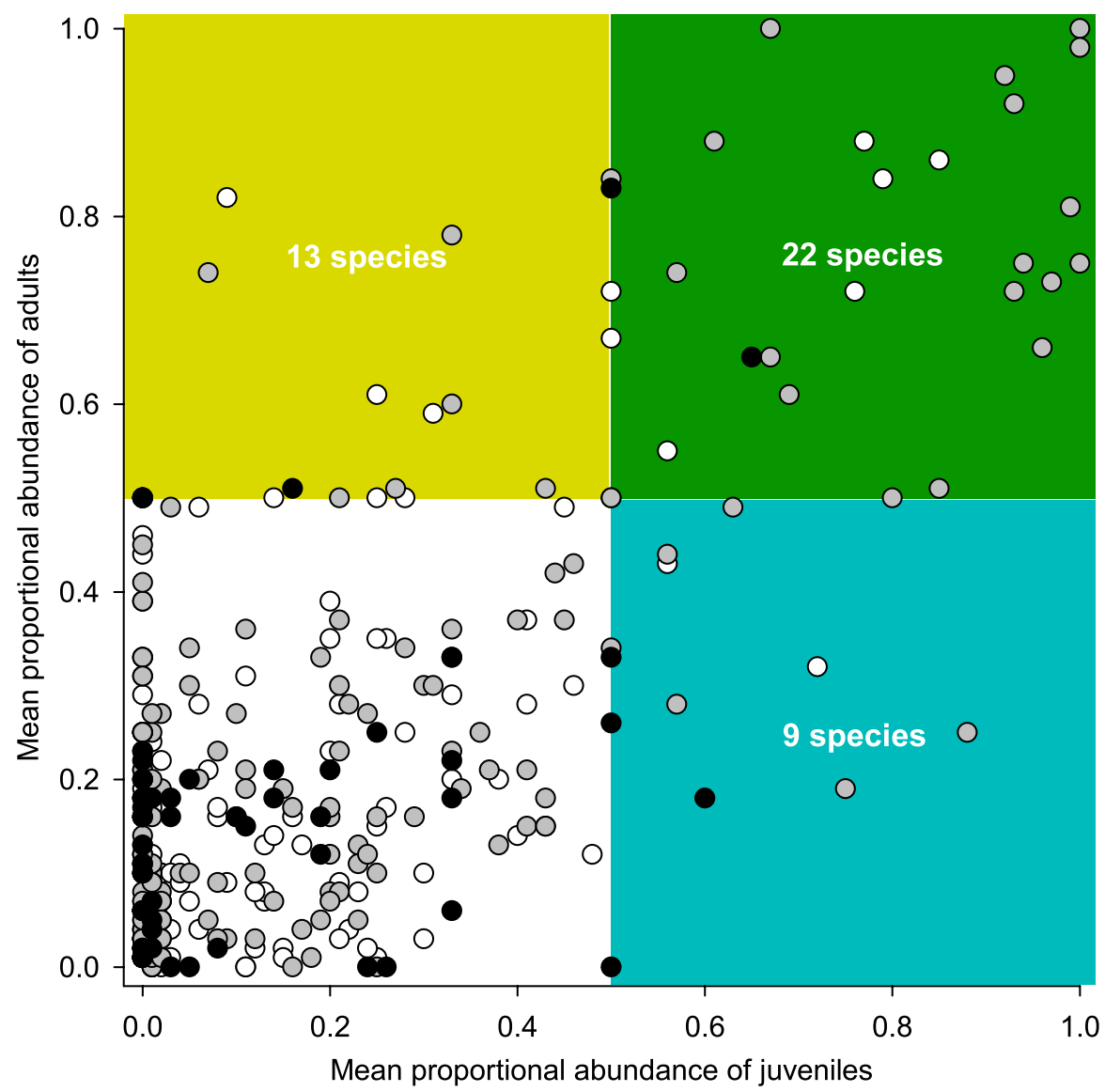

prey, such as the diverse and abundant epifauna found in macroalgal canopies (Martin-Smith, 1993; Tano et al., 2016; Wenger, van Lier, \& Fulton, 2018). While there is a relatively small component of tropical fish diversity that we may consider dependent on macroalgal habitat, our results point to a larger role of macroalgal-associated fishes in the functioning of marine ecosystems. Strong overlap in the occupation of macroalgal and other habitat types by species operating across several trophic levels suggests these fishes are functioning as mobile links that consume productivity within macroalgal meadows and then disperse this across tropical seascapes during foraging and/or ontogenetic migrations (Berkström, Lindborg, Thyresson, \& Gullström, 2013). Accordingly, macroalgal meadows should be considered one of several key habitats within a diverse and productive seascape that is needed to sustain healthy tropical fish populations and communities.

An important limitation of our analyses is that by only considering species with data across multiple independent studies, we are likely to exclude endemic species whose limited range inhibits the number of studies of their habitat ecology. For example, recruitment of the Leopard grouper (Mycteroperca roscacea, Serranidae) is reliably predicted by Sargassum cover (Aburto-Oropeza et al., 2007), but this species only occurs in the Eastern Central Pacific and there were insufficient independent empirical studies for this species to be highlighted in the trends discussed above. Similarly, cryptic species are not easily detected using underwater visual census, which is the prominent method for surveying fish (Murphy \& Jenkins,
2010). For example, abundance of the Finspot wrasse (Xenojulis margaritaceus, Labridae) is known to respond to canopy cover and composition (Wenger et al., 2018), but small body size and cryptic coloration mean this species is often not recorded in multitaxa visual surveys. Accordingly, we see the above as a conservative estimate of the number of macroalgal-associated fish species across tropical reef locations, with a bias towards diurnally active, conspicuous fish species of relatively large body size. Further research to identify small-bodied cryptic macroalgal-associated fishes is warranted, as these could be a considerable component of the overall tropical fish diversity with important implications for trophic flows of nutrients and energy (Brandl et al., 2019; Depczynski, Fulton, Marnane, \& Bellwood, 2007).

\section{3 | TROPICAL MACROALGAL MEADOWS AS FISH NURSERIES}

While the presence of a high number of juveniles seems an obvious requirement for a nursery habitat, this abundance of juveniles is irrelevant to future adult breeding populations unless they grow and survive to reproductive age (i.e. recruitment success). As such, the identification of a fish nursery habitat requires various lines of evidence, including the relative density, growth and survival rates of juveniles (Beck et al., 2001; Dahlgren et al., 2006; Gillanders, Able, Brown, Eggleston, \& Sheridan, 2003). This means 
the connectivity of habitats within a seascape is also of key importance for nurseries to be effective in replenishing adult fish populations (Beck et al., 2001; Berkström et al., 2012; Whitfield, 2017). Marine macrophyte habitats such as seagrass and mangroves have long been thought to provide this seascape nursery function (e.g. Beck et al., 2001; Gillanders et al., 2003; Whitfield, 2017). However, the comparative importance and ecological significance of tropical macroalgae as fish nursery habitats have yet to be fully assessed (Adams et al., 2006; Mellin, Kulbicki, \& Ponton, 2007). Here, we synthesize the evidence for macroalgal habitats to work alongside other common marine subtidal habitats to support the life cycles of tropical fishes.

Our compilation of relative fish abundance across 23 tropical locations confirms that macroalgal habitat use by juveniles is globally widespread and includes a remarkably wide range of tropical fish taxa. Of the 627 fish species found within macroalgal habitats across these locations, 64\% (399 species) were present as juveniles (Table S3). Over a third (147) of these 399 species present as juveniles in macroalgal habitats had their highest proportional abundance within macroalgal versus coral reef habitat (Table S3). Notably, several species with a high proportion of their juveniles within macroalgal habitat had the majority of their adults occupying nearby coral-dominated reef (e.g. Chocolate hind, Cephalopholis boenak, Serranidae; Yellowtail emperor, Lethrinus atkinsoni, Lethrinidae; Spangled emperor, Lethrinus nebulosus, Lethrinidae; Spanish flag snapper, Lutjanus carponotatus, Lutjanidae; Dory snapper, Lutjanus fulviflamma, Lutjanidae; and Three-ribbon wrasse, Stethojulis strigiventer, Labridae; Table S3). As such, macroalgal habitats seem to provide a key middle step in the triphasic life cycle of some tropical "coral reef" fishes (Mellin et al., 2007; Sambrook et al., 2019; Wilson et al., 2010). Importantly, these macroalgal-coral reef species play vital functional roles in tropical marine ecosystems (e.g. mesopredatory species of Cephalopholis and Epinephelus), and many are targeted by commercial and/or recreational fisheries (e.g. Epinephelus, Lethrinus and Lutjanus species).

Juvenile survivorship rates are a key quantum for identifying a fish nursery habitat, with piscivory a major driver of early life-history mortality (Beck et al., 2001). We found generally fewer piscivorous fish species within macroalgal meadows relative to nearby coral reef (e.g. fishes of highest trophic level in Figure 4; Fulton et al., 2019). While this suggests juvenile fish are subject to fewer types of piscivores in macroalgal habitats, more information is required to determine whether this translates to lower predation risk. Chief among these requirements is whether the local density of the relatively few resident piscivorous fish species is low relative to alternative habitats like coral reef or seagrass. There is the potential that some other resident fish species become facultative fish-feeders during seasonal periods of high juvenile abundance in macroalgal meadows (Holmes, Wilson, Vanderklift, Babcock, \& Fraser, 2012). Indeed, several species we identified as generalists/transients (Section 2) are piscivores that could periodically increase their abundance and foraging time within macroalgal meadows during periods of peak fish settlement. While it is possible that juvenile fish are subject to a relatively low diversity of piscivores relative to coral reef habitats, we have little evidence to conclude that macroalgal habitats confer higher rates of juvenile survival. We see this as a key research front that requires investigation of relative rates of predator mortality imposed on juveniles occupying a range of subtidal habitats within tropical seascapes.

Within a given habitat type, a certain combination of optimum local conditions can create patches that are particularly effective fish nurseries that contribute to future adult populations (Dahlgren et al., 2006; Nagelkerken, Sheaves, Baker, \& Connolly, 2015). Macroalgal habitats can vary considerably in canopy condition in ways that help explain differences in juvenile fish abundance over space and time. Percent macroalgal canopy cover, canopy height and/or density, as well as underlying attributes such as understory macroalgal cover, live coral and/or degree of underlying reef complexity have been linked to spatial and temporal variation in juvenile fish abundance (e.g. Eggertsen et al., 2019; van Lier, Wilson, Depczynski, Wenger, \& Fulton, 2018; Wenger et al., 2018). Besides direct selection by juvenile fish for certain microhabitat shelters, these variations in canopy condition are likely to influence the availability of preferred prey (either the macroalgae or their epibionts; Lim, Wilson, Holmes, Noble, \& Fulton, 2016; Wenger et al., 2018), with direct consequences for fish growth and survival. Indeed, a combination of macroalgal meadow condition and juvenile abundance were key predictors for the future abundance of Lethrinus subadults in the eastern Indian Ocean (Wilson et al., 2017), a finding that is consistent with an earlier study linking Sargassum condition to the recruitment success of the Pacific Ocean Leopard grouper in the eastern Pacific (AburtoOropeza et al., 2007). Changes in canopy complexity could also influence the success of piscivores to capture juvenile fish. However, the evidence for the latter remains equivocal, with studies in marine macrophyte habitats finding fish predator success was either affected greatly by differences in canopy structural complexity, or not at all (e.g. Horinouchi, 2007; Pérez-Matus, Sánchez, GonzálezBut, \& Lamb, 2016).

Seascape context could also play a key role in determining the nursery quality of patchy habitats (Nagelkerken et al., 2015). Structural connectivity, measured as the proximity of a meadow patch to other viable habitats within the seascape, is emerging as an important predictor of juvenile abundance and diversity in macroalgal habitats (e.g. Bradley, Baker, Nagelkerken, \& Sheaves, 2019; Mellin et al., 2007; van Lier et al., 2018). This is likely to be particularly important for ontogenetic migrations, such as the movement of key fishery target species (e.g. some Lethrinus species) from macroalgal to adjacent coral reef habitat as they increase in body size from juveniles to subadults (Wilson et al., 2017). In such species, both the canopy quality (e.g. composition, percent cover, height, density) and proximity of macroalgal patch habitats are likely to shape the magnitude of fish recruitment across diverse tropical seascapes (Nagelkerken et al., 2015; Wilson et al., 2017). From a management perspective, identifying these high-quality and connected macroalgal patches should be a priority to ensure protection of key sources of fish population replenishment. 


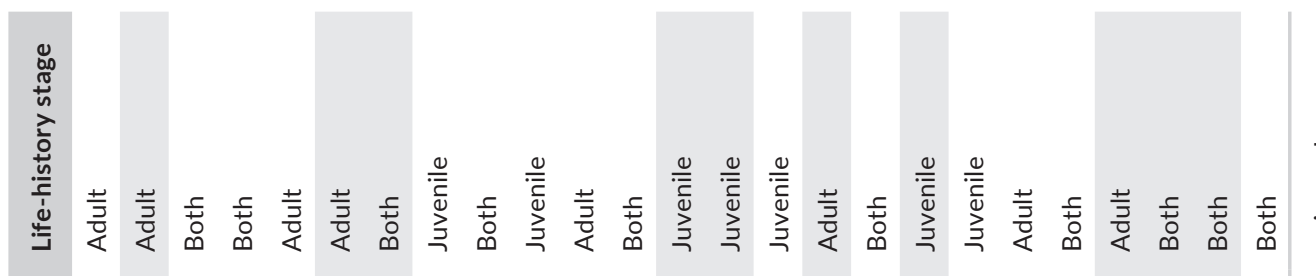

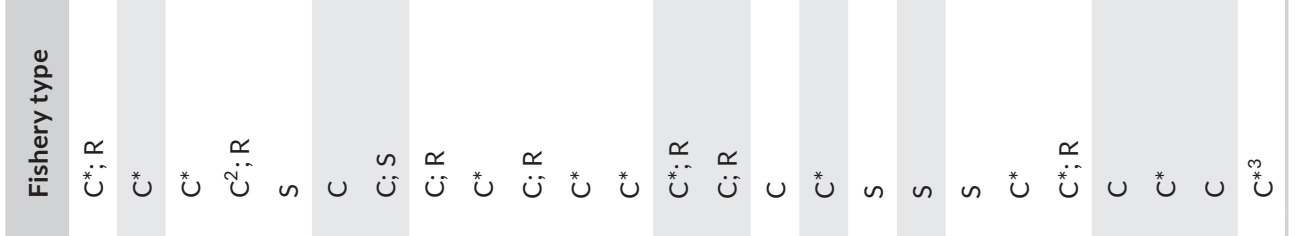



U U _ _ _ I I

î



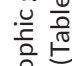

焉

离

苦

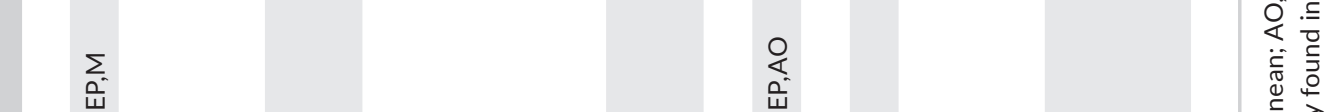

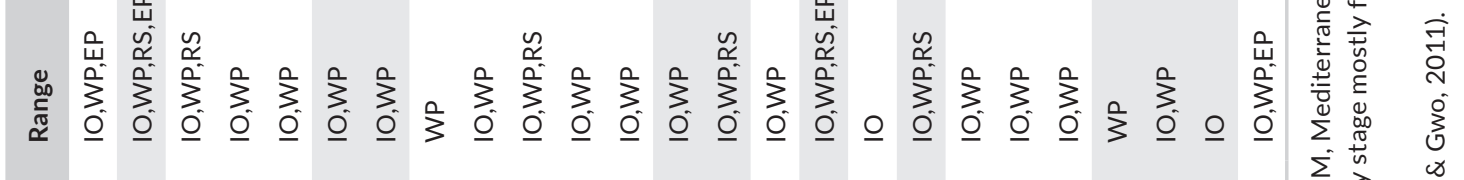

$\underset{\underline{E}}{\bar{E}}$

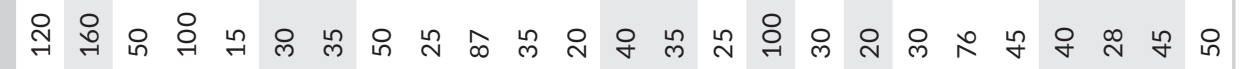

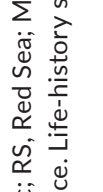



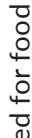

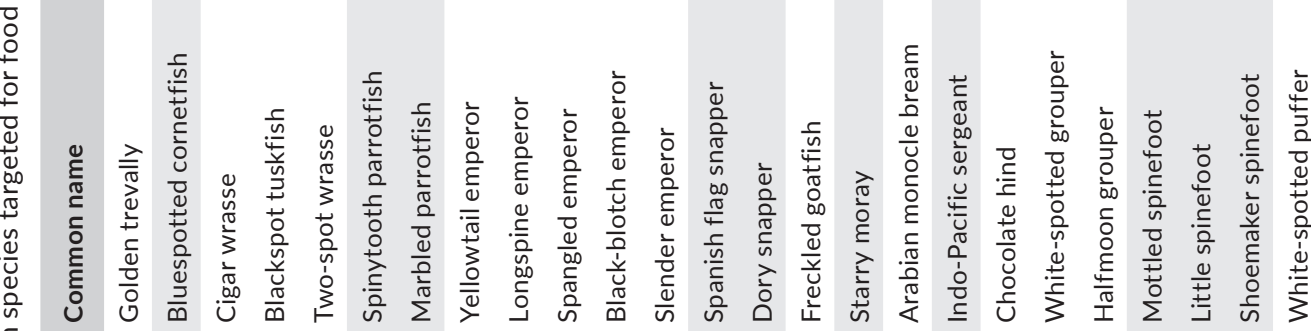

离

혼

品

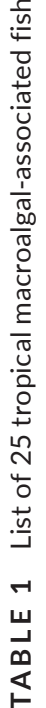
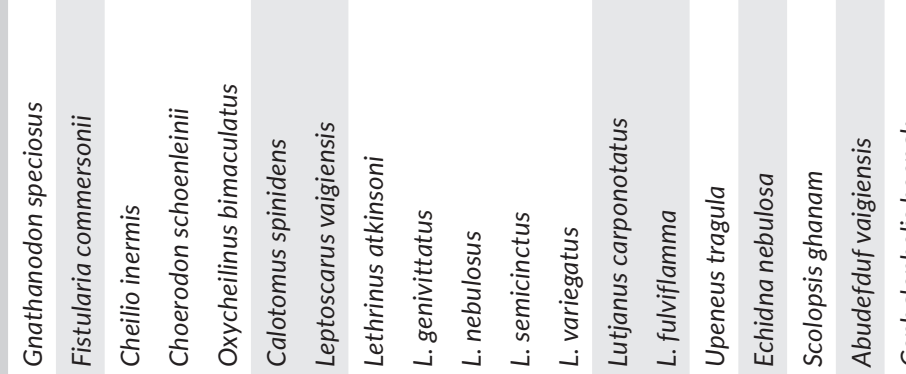

胥

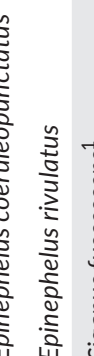

崩

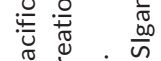

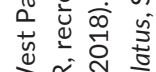



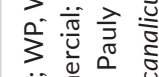





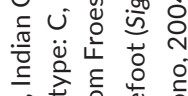

葛
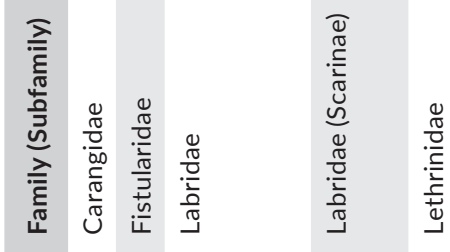



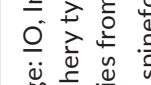

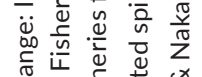



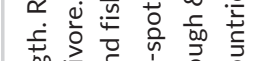



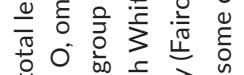

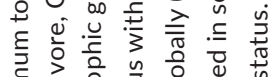

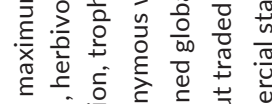


Published and emerging evidence lends support to two criteria for tropical macroalgal meadows functioning as fish nurseries: (a) they are widely used by juveniles of tropical reef fishes, many of which have the majority of their juvenile abundance within macroalgal habitats but are later found on coral reefs as adults; and (b) macroalgal habitat quality during the juvenile phase can influence the future abundance of subadult and adult fish populations (e.g. Aburto-Oropeza et al., 2007; Wilson et al., 2017). Evidence for the former is much stronger and widespread than for the latter. Our analyses do not provide evidence of the link between macroalgal habitat availability and future fish population sizes, only evidence of patterns of occupation and proportional abundance. Nonetheless, for species whose juveniles are exclusively found within macroalgal habitats, it is likely this habitat type provides a nursery function, as long as all available habitats in the seascape have been adequately surveyed (Beck et al., 2001; Dahlgren et al., 2006). For future work, we suggest fish taxa with juveniles that utilize a range of purported nursery habitats (Figure 3-"both" category) could be prime targets for testing whether macroalgal habitats facilitate increased fish growth, survivorship and recruitment success (sensu Beck et al., 2001; Dahlgren et al., 2006).

\section{I MACROALGAE-ASSOCIATED TROPICAL FISHERIES}

Tropical macroalgal habitats likely play several roles in supporting local fisheries production. First, as with kelp forests (see Bertocci et al., 2015; Brown et al., 2018), macroalgal production may enhance fishable biomass through direct consumption by browsing herbivores (e.g. Spinytooth parrotfish, Calotomus spinidens, Labridae; Marbled parrotfish; and some Siganus species; Fox \& Bellwood, 2008; Hoey, Brandl, \& Bellwood, 2013; Unsworth, Taylor, Powell, Bell, \& Smith, 2007; Table 1). These herbivorous taxa have some of the highest rates of secondary production (i.e. rapid somatic growth and short longevity) among targeted reef fishes, enabling them to withstand high fishing pressure (Hicks \& McClanahan, 2012; Morais \& Bellwood, 2018). Secondly, macroalgae-derived detrital subsidies may be substantial in regions with extensive Sargassum beds because of the annual canopy loss in these habitats (Fulton et al., 2019). Macroalgal detritus may then be consumed by a wide range of invertebrates and grazing fishes across macroalgal and other habitat types that receive biomass subsidies through the drift of algal rafts and wrack (Stimson, 2013; Wilson, Bellwood, Choat, \& Furnas, 2003; Zubia, Andréfouët, \& Payri, 2015). Thirdly, canopy-forming macroalgae promote the production of epifaunal invertebrates that are preyed upon by smaller carnivorous fishes, thereby facilitating multiple routes for higher-order production involving resident and transient carnivorous fishes, in addition to predation on herbivorous fishes (Edgar \& Aoki, 1993; Rossier \& Kulbicki, 2000; Wenger et al., 2018). The importance of macroalgal habitats as foraging areas for some guilds of carnivorous fish may even exceed that of seagrass beds due to higher diversity, abundance and biomass of epifauna
(Tano et al., 2016). Aside from these trophic pathways, structurally complex macroalgal communities may also serve as nursery habitats for the juveniles of targeted reef fish (Section 3). This means strong seasonal and interannual fluctuations in macroalgal habitat quality are likely to have direct implications for recruitment and future fishery yields (Lim et al., 2016; Wilson et al., 2017).

Over half of the 44 fish species most strongly associated with tropical macroalgal meadows (Section 2, Table S3) are targeted by commercial, subsistence or recreational fisheries (Table 1). Targeted species include herbivores in the families Siganidae and Labridae (subfamily Scarinae), as well as larger-bodied (>30 cm maximum length) generalist carnivores (Lethrinidae, Serranidae) and invertivores (Labridae). While many of these species are of minor commercial importance for industrial-scale fishing, they collectively represent a major component of production in small-scale fisheries that are significant for local communities. Estimating the contribution of macroalgal habitats to tropical fisheries is, however, problematic due to the lack of species- or habitat-specific data in global fisheries statistics (FAO, 2018). Furthermore, global data are likely to under-represent or completely exclude small-scale fisheries that target macroalgae-associated species (McClanahan, Hicks, \& Darling, 2008; McManus, Nañola, Reyes, \& Kesner, 1992; Pauly \& Zeller, 2016). Taking one family of herbivorous and detritivorous fishes as a model, the rabbitfishes (Siganidae; FAO, 2018), we may get some indication of the importance of tropical macroalgal habitats to food security on a global scale (Table S5). Catch data for this family are mainly for herbivorous rabbitfish that school in large numbers and utilize macroalgal habitats, rather than the coral reef-associated pair-forming rabbitfish species (Campos et al., 1994; Hicks \& McClanahan, 2012; Hoey et al., 2013; Robinson et al., 2018). Rabbitfishes are targeted in at least 23 countries where they typically account for a small proportion (median $=1.3 \%$ ) of national aggregated marine fish landings, although their contribution can be more substantial in some countries (17\% in Kenya; $32 \%$ in Bahrain; Table S5). Importantly, 77\% of the reported global rabbitfish catch occurs in Indonesia and the Philippines, two low-income countries, with high human populations and extensive coral reefs threatened by overfishing (Burke, Reytar, Spalding, \& Perry, 2012), and where the importance of rabbitfishes as a food source is increasing (Figure 5). In the Philippines, annual rabbitfish catch has grown gradually over the past half-century, surpassing snapper (Lutjanidae) landings within the last two decades. In contrast, the trend in Indonesia suggests a more recent and rapid increase, with rabbitfish approaching emperor (Lethrinidae) landings in the past decade (Figure 5). Some of this growth in herbivorous fish catches may have been linked to the expansion of seaweed farming in these countries, which has increased the macroalgal habitat and trophic resources available to fishes in shallow reef habitats (Hehre \& Meeuwig, 2016).

Case studies of small-scale fisheries operating in shallow reef areas often dominated by macroalgal habitat suggest high yields of macroalgae-associated fishes at high levels of fishing effort (Campos et al., 1994; McManus et al., 1992). Total fish yields of 12-16 metric tons $\mathrm{km}^{2} \mathrm{yr}^{-1}$ from back reefs have been reported in the Philippines and Kenya, respectively (McClanahan et al., 2008; McManus et al., 

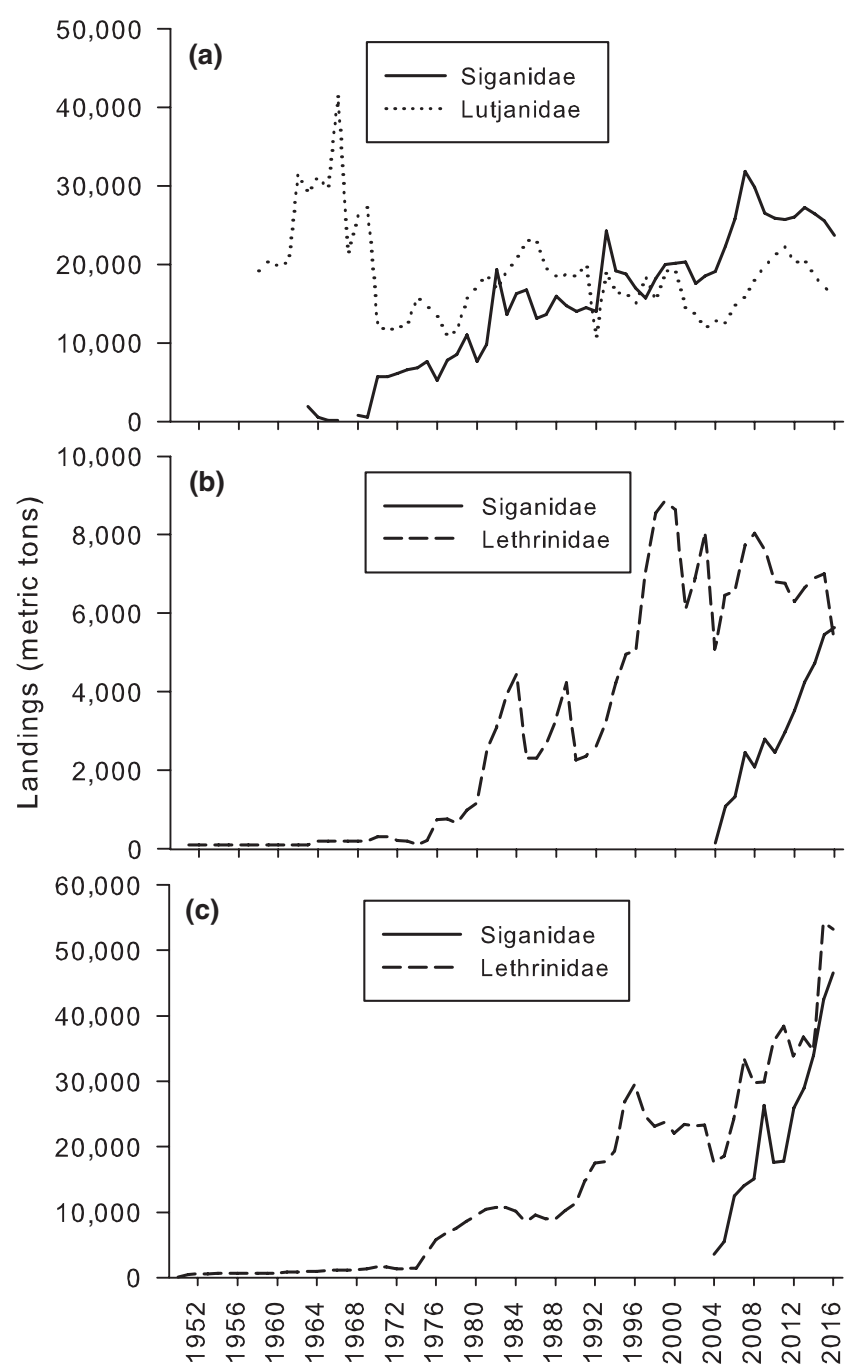

FIGURE 5 Landings of rabbitfish (Siganidae), snapper (Lutjanidae) and emperor (Lethrinidae) in the Philippines (a) and Indonesia (b-Pacific Ocean; c-Indian Ocean) from 1950 to 2016 (FAO, 2018)

1992). These yields exceed mean reported annual fish yields from coral reefs in the Pacific and Indian Ocean (McClanahan, 2006) and are more than 2 to 3 times the global maximum sustainable yield from coral reefs (Newton, Côté, Pilling, Jennings, \& Dulvy, 2007). However, macroalgae-associated fishes that dominate yields may be at a high risk of overfishing in some localities. In Kenya, two herbivorous species, Marbled parrotfish and Shoemaker spinefoot (Siganus sutor, Siganidae), which together constitute over $60 \%$ of the total catch of small-scale reef fisheries by weight, have shown symptoms of growth and recruitment overfishing (Hicks \& McClanahan, 2012). Similarly, in the Philippines, stocks of Mottled spinefoot (Siganus fuscescens, Siganidae) and Little spinefoot (Siganus spinus, Siganidae) are at severe risk of recruitment overfishing because both the adults and very young juveniles are targeted (McManus et al., 1992; Soliman \& Yamaoka, 2010). As a consequence, smaller size-at-maturity and lower fecundity have been observed where fishing pressure is high (JumawanNanual \& Metillo, 2008; Soliman \& Yamaoka, 2010). Since these macroalgae-associated rabbitfish can form large transient spawning aggregations targeted by fishers (Bijoux et al., 2013; McManus et al., 1992; Robinson, Graham, Grüss, Gerry, \& Bijoux, 2017; Robinson et al., 2011), they are particularly susceptible to overfishing. However, fast somatic growth, early maturation and high fecundity, along with variable catchability are thought to limit the vulnerability of this fishery to over-exploitation (Campos et al., 1994; Robinson et al., 2017).

Tropical macroalgal habitats may appear to make a minor contribution to global fisheries production, but like coral reefs, macroalgal meadows can underpin and enhance the food security and livelihoods of coastal communities that have few other sources of income (Cabral \& Geronimo, 2018). Even in wealthy countries, the indirect contribution of macroalgal habitats to recreational fisheries and local economies may be substantial. For example, at Ningaloo in Western Australia, recreational fishing is a major driver of tourism (Smallwood, Beckley, \& Moore, 2013) and two commonly caught species, Halfmoon grouper and Spangled emperor (Ryan et al., 2017), utilize macroalgal habitats (Table 1). The potential for tropical macroalgal habitat to be fish nurseries, trophic facilitators, and corridors for fish movement between habitats suggest they warrant the same recognition as mangroves, seagrass beds and coral reefs in ecosystem-based fisheries management. Spatial management and monitoring of tropical macroalgal habitats could then provide capacity for the adaptive management of habitat-based fluctuations in fishable biomass of coastal target species (Brown et al., 2018; Green et al., 2014). This will require more quantitative information on the key aspects of macroalgal habitat quality and connectivity that affect both standing fish biomass and recruitment, and how these habitat traits respond to climatic cycles and disturbance events (Aburto-Oropeza et al., 2007; Wilson et al., 2017, 2018).

Apart from over-exploitation, the other major threat to the sustainability of tropical fisheries is habitat loss, especially the loss of hard corals due to climate change (Bell et al., 2013; Newton et al., 2007). One of the responses of coral reefs to live coral loss is a regime shift from a coral-dominated to a macroalgal-dominated state (e.g. Graham, Jennings, MacNeil, Mouillot, \& Wilson, 2015). The implications of such a shift in habitat are anticipated to be detrimental to the yield of coral reef fisheries (Graham et al., 2007; MacNeil et al., 2010; Pratchett, Hoey, \& Wilson, 2014; Pratchett et al., 2008). However, data to assess long-term implications of regime shifts on tropical fisheries are scant. An exception is in the Seychelles, where long-term assessments of the inshore trap fishery found that yield and CPUE have been maintained or even increased following widespread bleaching and a shift to macroalgal-dominated habitat on some reefs (Robinson et al., 2018). Variability in the catch, however, has increased and on reefs that underwent a regime shift the trophic structure of the fish assemblage was altered to shortened food chains with increases in biomass of low-trophic level herbivores and mid-level carnivores, such as emperors (Hempson, Graham, MacNeil, Hoey, \& Wilson, 2018). Therefore, while the catch has been maintained with a shift towards macroalgae-associated herbivorous fish, the predictability of catch per fishing trip has become less certain (Robinson et al., 2018). 


\section{5 | VULNERABILITY OF MACROALGAL FISHES TO HABITAT LOSS}

Macroalgal meadows are sensitive to environmental fluctuations and local disturbances (Olsen et al., 2019). Annual productivity of canopy-forming macroalgae is closely related to seasonal shifts in water temperature, although the range and optimal temperature for growth vary among taxa and regions (Fulton et al., 2019). As such, both local seasonal and large-scale climatic oscillations in sea temperature, such as those associated with the El Niño Southern Oscillation, can alter the structure of tropical macroalgal habitats (Fulton et al., 2019; Wilson et al., 2014, 2018). Similarly, extreme climatic events like heatwaves and cyclones can cause extensive loss of macroalgal habitat, with reduced macroalgal canopy cover often persisting for several years after the event (McCourt, 1984; Rogers, 1997; but see Loffler \& Hoey, 2018). Long-term shifts in climate are also expected to alter the distribution and abundance of macroalgal species, leading to changes in community composition and ecosystem function (Diaz-Pulido et al., 2007). Over finer spatial scales, experimental manipulation of nutrient concentrations (Schaffelke \& Klumpp, 1998) and sediment loads (Umar, McCook, \& Price, 1998) demonstrate that environmental conditions can have a direct effect on macroalgae canopy phenology. Nutrient pulses and increased sediment loads associated with natural disturbances such as flooding, or human activities such as dredging and coastal development, are therefore expected to have a local impact on canopy cover and structure within macroalgal habitats.

Acute and continuous stressors that affect the structure of tropical macroalgal habitats are also expected to have an impact on the associated fishes. Ecological theory suggests that species most severely affected by disturbances will be those that feed or shelter exclusively within macroalgal habitats (Vázquez \& Simberloff, 2002). Such macroalgal specialists might be especially vulnerable during the early life-history stages when juvenile fishes are highly susceptible to predation and take shelter within particular aspects of macroalgal habitat microstructure. Changes in availability of dietary resources within macroalgal meadows may also influence fish growth and abundance, given the role they play in supporting direct (herbivorous) and indirect (carnivorous) food sources (Fulton et al., 2019). However, studies that have explicitly assessed the influence of disturbances on tropical macroalgal meadows and their associated fish fauna have been limited to fine-scale macroalgal removal experiments (e.g. McClanahan, Hendrick, Rodrigues, \& Polunin, 1999) or long-term comparisons of reefs that have undergone regime shifts from coral to macroalgal-dominated states (Graham et al., 2015).

Our meta-analysis of the correlation between fish abundance and varying macroalgal cover across a range of tropical locations around the world (Table S1) identified fish species and life-history stages that are likely to be macroalgal-dependent and most affected by macroalgal habitat loss. Using Pearson's correlation adjusted for survey area in a weighted z-score, averaged across a minimum of three independent surveys per life-history stage of each species (see Section 4 of Methods), we found a spectrum of relationships between the abundance of macroalgal-associated fishes and percent macroalgal cover (Figure 6). Some species had a significant positive relationship with macroalgal canopy cover (i.e. a positive mean z-score with confidence interval above zero, indicated by hashed bars above the centre line, Figure 6), increasing in abundance when cover was high and declining when it was low. For Marbled parrotfish (Leptoscarus vaigiensis, Labridae) and Cigar wrasse (Cheilio inermis, Labridae), this positive relationship was strong for both adults and juveniles (Figure 6), while for other species the general relationship differed in direction or significance among life-history stages, suggesting ontogenetic shifts in macroalgal habitat dependence. For example, the abundance of juvenile Spangled emperor (Lethrinus atkinsoni, Lethrinidae) was strongly correlated with canopy cover, but this relationship was not apparent for larger conspecifics (Figure 6), which are typically found on nearby coral reef (Wilson et al., 2017). Conversely, the abundance of adult Halfmoon grouper (Epinephelus rivulatus, Serranidae) positively correlated with macroalgal canopy cover, while the abundance of their juveniles did not (Figure 6), which suggests an increased dependence on macroalgal habitats with ontogeny. There were also several species that consistently declined in abundance as macroalgal canopy cover increased (Threeline damsel, Pomacentrus trilineatus, Pomacentridae; Spotted sharpnose, Canthigaster solandri, Tetraodontidae; Harlequin sweetlip, Plectrorhincus chaetodonoides, Haemulidae; and Bluespotted cornetfish; Figure 6), implying that these macroalgal-associated fishes, which were predominantly found in macroalgal meadows rather than coral reef, may prefer macroalgal habitats with low cover.

Our meta-analysis suggests that the extent of macroalgal dependence in tropical fishes varies both interspecifically and ontogenically when considering only percent cover of canopy-forming macroalgae. The within-meadow canopy structure of macroalgal meadows, however, is often a conglomerate of multiple factors and fishes may associate with specific architectural components of the three-dimensional macroalgal canopy habitat. Previous studies have, for example, identified that abundance of fishes can also correlate with canopy height (Eggertsen et al., 2019; Evans, Wilson, Field, \& Moore, 2014; Lim et al., 2016) or the density of canopy-forming macroalgae holdfasts (Wilson et al., 2014, 2017). Using 6 years of fish and habitat surveys at 19 sites spread across the Ningaloo lagoon in the eastern Indian Ocean, we compared annual patterns of fish abundance with canopy cover, height and density to identify which macroalgal structural elements consistently predict fish abundance (Figure 7). Some species, like Marbled parrotfish and Spangled emperor, clearly have strong positive correlations with multiple facets of macroalgal canopy structure, while the abundance of others (e.g. juvenile Three-ribbon wrasse, Stethojulis strigiventer, Labridae) primarily correlate with a single canopy feature such as height (Figure 7b). Interestingly, the abundance of adults and juveniles of the same fish species often correlate with the same elements of macroalgal canopy structure, but juveniles typically have stronger canopy-abundance relationships (Figures 6 and 7). This suggests the early life-history stages of most species may be more habitat dependent and vulnerable to environmental 


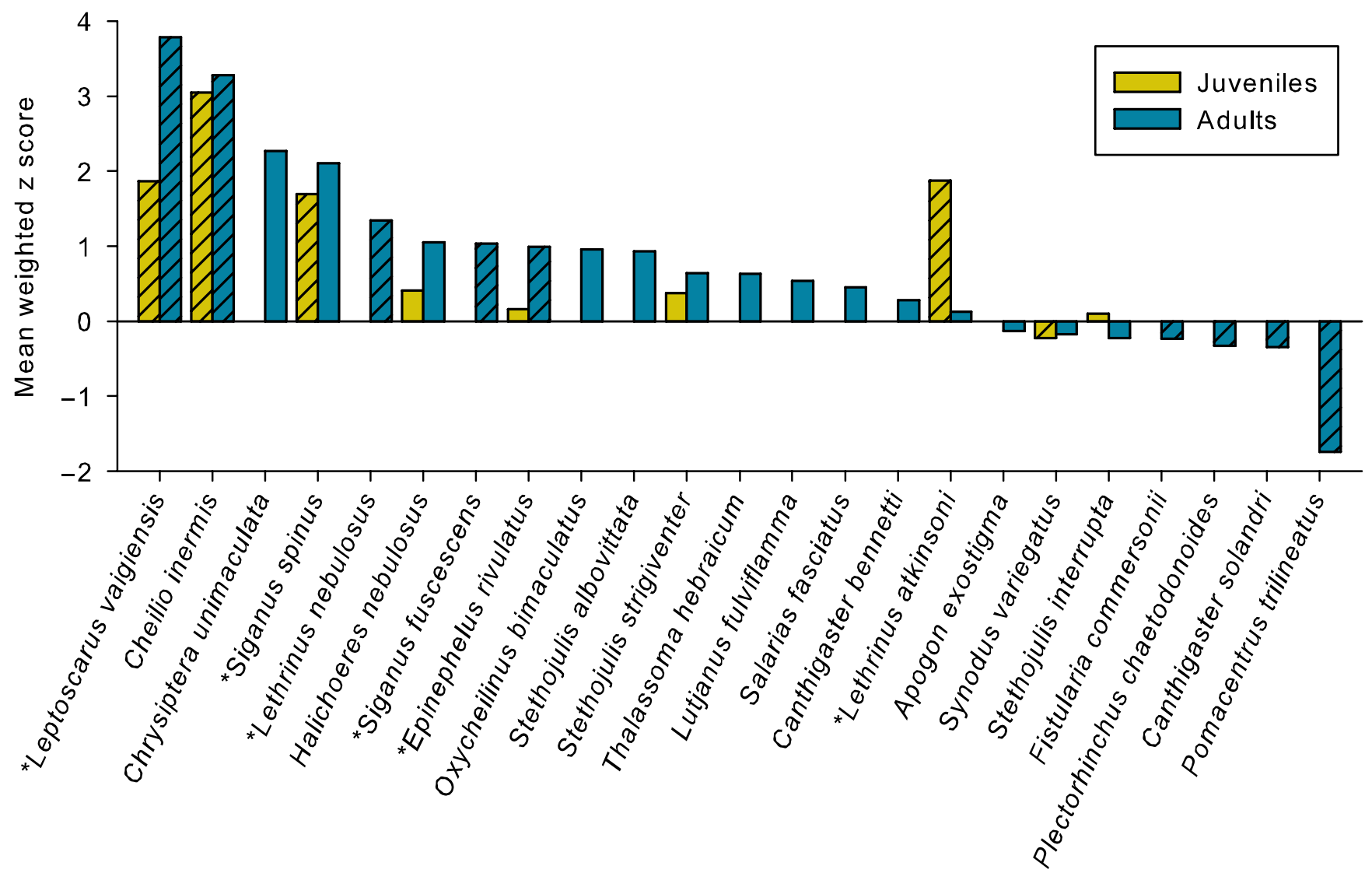

FIGURE 6 Relationship between the abundance of 23 fish species and macroalgal habitat cover across geographic locations encompassed by our meta-analysis. Mean weighted z scores indicate species with positive (increased abundance) or negative (decreased abundance) relationships with macroalgal cover (replication per species and life-history stage are provided in Table S3). Hatching denotes the scores with $95 \%$ confidence limits that fail to intersect zero, which indicates a consistent response across locations. An asterisk indicates a species is targeted for fishing in one or more of the survey locations (Table 1). Note figure appears in colour in the online version only

disturbances acting on macroalgal meadows. Temporal mismatches that arise between peak macroalgal habitat availability and seasonal pulses of larval fish settlement may, therefore, directly affect the survival of juveniles with long-term consequences for the replenishment of adult populations. However, experimental manipulations of habitat structure and reciprocal removal of competitive fishes are required to understand the true extent of habitat limitation, competition and recruitment facilitation in macroalgal meadows. A key challenge in these experiments will be manipulating certain aspects of canopy condition while keeping others constant (e.g. reducing height while maintaining cover) in order to tease apart specific habitat effects.

Different levels of dependence upon particular canopy structural features may allow partitioning of resources and co-existence of species (Wilson et al., 2014, 2017), which could explain the spectrum of relationships between canopy structure and the diversity and abundance of macroalgal-associated fishes at Ningaloo (see Figures S1-S4). Although herbivorous fishes on coral-dominated reefs can respond negatively to increasing canopy density in experimental patches of macroalgal habitat (Hoey \& Bellwood, 2011), we found the overall abundance of macroalgae-associated herbivorous and carnivorous fishes generally increased with macroalgal canopy density, height and cover at Ningaloo (Figures S1 and S2). Species-specific relationships are less clear (Figures S3 and S4), and while we found some evidence for negative correlations between canopy density and the abundance of two common macroalgal-associated herbivorous fishes (Blue-barred parrotfish, Scarus ghobban, Labridae; and Mottled spinefoot, Siganus fuscescens, Siganidae; Figure S3), the most abundant macroalgal meadow herbivore in our data set (Marbled parrotfish) responded positively to increases in canopy cover, height and density (Figure S3g-i). We are prevented from making generalizations on the nature and drivers of these relationships by a lack of diversity in the types of macroalgal habitat data collected by studies-the majority to date have been focused on percent cover. Macroalgal percent cover is unlikely to be a good predictor for other measures of canopy structure, given the disparity between the two metrics (Lim et al., 2016; Wilson et al., 2014). Indeed, studies at various locations around the world report that neighbouring macroalgal meadows within a tropical seascape can vary considerably in canopy cover, height and/or density, and that taxonomic and trophic groups of macroalgal fishes respond in different ways to this canopy complexity over space and time (e.g. Eggertsen et al., 2017; Eggertsen et al., 2019; Wilson et al., 2017). 




FIGURE 7 Correlations between the abundance of 28 fish species and mean annual ( $n=6$ years) macroalgal canopy habitat structure in terms of (a) percent cover, (b) height, and (c) density of holdfasts across 19 study sites at Ningaloo, Western Australia. Pearson's correlation indicates species with positive (increased abundance) or negative (decreased abundance) relationships with macroalgal canopy structure. Hatching denotes the scores with $95 \%$ confidence limits that fail to intersect zero, which indicates a consistent response among years. Note figure appears in colour in the online version only 
Based on the evidence to date, canopy height and cover could arise as some of the best habitat-based predictors for temporal trends in macroalgal fish-habitat relationships, as these aspects often vary the most over time, while canopy density is relatively stable within meadows but can vary considerably among sites (e.g. Lim et al., 2016; Umar et al., 1998; Wilson et al., 2014). To test these general hypotheses, we need more studies to include measures of canopy height and density (alongside percent cover) to resolve which aspects best predict fish community structure and function in tropical macroalgal meadows.

Limited evidence suggests fishes may also associate with certain macroalgal species or genera (e.g. Sargassum; Lim et al., 2016, Wenger et al., 2018). While we lack the information needed to assess macroalgal-specificity in a wider suite of tropical fishes, this should be an important line of research because this lack of ecological versatility can render fishes more susceptible to disturbances that affect specific macroalgae. Moreover, habitat features other than the composition and soft habitat structure afforded by the macroalgae could influence fish abundance. For instance, the structural complexity of the underlying hard substratum or availability of shelter holes may be a better predictor of abundance for some macroalgal fish species (Eggleston, 1995). The influence of hard substratum complexity (e.g. presence of live/dead corals, holes, crevices and/or general topographic variation) on fish communities has been well documented in coral-dominated systems (Graham \& Nash, 2013), but has received minimal attention in macrophyte systems. Recent surveys in the western Indian Ocean found the abundance of juvenile fishes was greater in macroalgal meadows with more structurally complex hard substrate (Eggertsen et al., 2019). Hard habitat complexity has also emerged as an important predictor of macroalgae-associated adult fish communities at Ningaloo (van Lier et al., 2018). A more in-depth analysis of data from van Lier et al. (2018) revealed macroalgal meadows with high hard substratum complexity were often characterized by species typical of coral reefs (e.g. Moon wrasse, Thalassoma lunare, Labridae; Figure S5). Fishes exclusively found in macroalgal habitats, however, displayed a mixed relationship with hard substratum complexity (Figure S5). For instance, abundance of the herbivorous browser Marbled parrotfish was not unduly related to hard substratum complexity, while a predatory fish (Halfmoon grouper) tended to occupy meadows with greater hard substratum complexity (Figure S5). Before any generalities can be drawn, we need more assessments of how fine-scale changes in both soft macroalgal and hard substratum habitat structures influence macroalgal fish communities across a greater range of tropical settings.

Spatial arrangement and proximity of macroalgal meadows to other tropical habitat-forming taxa may also have an important bearing on fish diversity and abundance (Berkström et al., 2012; Bradley et al., 2019; Martin et al., 2018). Macroalgal meadows are often located in the vicinity of other habitats, forming a mosaic of interlinked patches in diverse tropical seascapes. Functional linkages among habitat patches support the persistence of marine populations and communities and are pivotal for enabling ecosystems to persist and recover from disturbances (Cumming, 2011; Olds et al., 2018). Consequently, disturbances that disrupt connectivity among habitats are expected to have the greatest effect on those species that migrate among habitats within the seascape (Dahlgren \& Eggleston, 2000), such as the many fish species that appear to migrate from macroalgal to other habitats during their ontogeny (Section 3). Adult fishes may also regularly move among different patches or habitats types to forage. For example, some of the strongest and most consistent relationships between canopy cover and abundance occur with adult Moon wrasse and Spangled emperor (Figures 6 and 7), highly mobile species that may move among meadows and other habitat types within diverse tropical seascapes. Clearly, more seascape studies that incorporate macroalgal habitats are required to improve our understanding of the consequences of habitat destruction and fragmentation within tropical seascapes.

Disturbances that alter the structure and composition of macroalgal communities can also result in ecologically novel situations for fish. Ecological novelty can be difficult to navigate for animals that lack relevant evolutionary experience (Sih, Ferrari, \& Harris, 2011) and individuals that incorrectly assess habitat quality may fail to make the most of available habitat options (i.e. fall into ecological traps; Hale \& Swearer, 2016). As a result, fish populations could be affected disproportionately to the level of changes in overall habitat condition (Hale, Treml, \& Swearer, 2015). Numerous ecological traps have been revealed in terrestrial habitats (Hale \& Swearer, 2016), and analogous cases are likely to arise in macroalgal systems. For example, via habitat fragmentation and subsequent failure of individuals to avoid risky patch edges (sensu Weldon \& Haddad, 2005), or via fishes utilizing non-native or range-expanding macrophytes that offer superficially similar habitat but lower quantity of resource provision throughout the relevant season (e.g. Hempson, Graham, MacNeil, Bodin, \& Wilson, 2018; Rodewald, Shustack, \& Hitchcock, 2010). Smallbodied juveniles, as well cryptic and endemic fishes with limited capacity to move to alternate habitats may be the most vulnerable to changes in macroalgal habitat. Conversely, larger-bodied species that have a generalist carnivore diet and generalist habitat associations (e.g. 'transient' fish taxa identified in Section 2) may have the capacity to readily move among patches and adapt to macroalgal habitat loss (Berkström et al., 2013). Fish species that overlap in their habitat occupation of macroalgal meadows and seagrass beds (Figure 3) may be particularly resilient to habitat disturbances affecting one habitat-forming organism in a diverse tropical seascape. However, even among these species, our meta-analysis of macroalgal-associated fishes and published studies on seagrass fish faunas (e.g. Eggertsen et al., 2017; Tano et al., 2017) suggest strong preferences for certain types and quality of macrophyte habitat. The negative effects of changes in coral canopy condition have been well documented in reef fishes that prefer certain hard coral species and growth forms (e.g. Pratchett et al., 2014; Pratchett et al., 2008; Wilson, Graham, Pratchett, Jones, \& Polunin, 2006). Accordingly, shifts in the availability of 
preferred macrophyte canopy habitats are likely to have a detrimental impact on the abundance and/or condition of macrophyte specialist fishes.

\section{6 | CONCLUSIONS}

Macroalgal habitats can be a substantial component of tropical seascapes around the world. Our synthesis has revealed that macroalgal meadows can support a unique component of tropical fish species richness, may be an important factor in shaping fish recruitment across diverse tropical seascapes, and may provide a key habitat for productive species that support local fisheries. While over 600 species of bony fishes have been recorded in tropical macroalgal meadows around the world, at present there is only evidence to suggest a quarter to a third of those species have the majority of their juvenile and/or adult abundance within macroalgal habitat. Using the relatively few studies for which there are balanced visual surveys of fish species richness across different habitat types, we found considerable overlap between fish assemblages within macroalgal habitats and two other common subtidal habitats-seagrass and coral reefs-which suggests macroalgal meadows could also be important foraging habitats and/ or stepping stones in the triphasic life cycles of fishes in diverse tropical seascapes.

Juvenile fishes appear to be prominent in macroalgal habitats across the tropics, where the quality of macroalgal canopy (percent cover, height and/or density) can be positively correlated with the abundance of juveniles. Evidence from two studies (in the Eastern Pacific and Western Indian oceans) suggests these habitat effects during the juvenile phase could influence the future abundance of fish in larger/older size-classes (Aburto-Oropeza et al., 2007; Wilson et al., 2017). While this is suggestive that canopy-forming macroalgal habitats may serve as fish nurseries, we lack key lines of evidence to make a general conclusion. More information on rates of juvenile growth, survival and movement is needed before we can establish the potential nursery function of macroalgal meadows for tropical fish and fisheries. Similarly, we need greater resolution on the catch of macroalgal-associated fishes to fully understand the contribution of macroalgal habitats to tropical fisheries.

Compared to other prominent tropical habitats like coral reefs, macroalgal meadows can be particularly dynamic in structure over space and time, which has major consequences for the abundance and distribution of many macroalgal-associated fishes. Environmental conditions such as sea temperature are important drivers of this dynamism, which suggests climate change may affect tropical canopy-forming macroalgae and the associated fish communities and fisheries. Significantly, not all tropical macroalgal patches respond in the same way to seasonal and interannual changes in climate, with some patches in the seascape retaining canopy and providing a key habitat refuge (Lim et al., 2016; Wilson et al., 2017). Accordingly, we need to identify what makes certain macroalgal patches resilient to disturbance, and at what scale this needs to be maintained in order to facilitate functional connectivity with other tropical habitats. This will require long-term monitoring of fish abundance across tropical seascapes, and assessments of how seasonal changes to macroalgal canopy structure affect patterns of fish distribution and replenishment across a suite of habitat types within tropical seascapes. Indeed, a lack of information on macroalgal fish assemblages over prolonged periods has restricted our understanding of how these fish contribute to key ecological processes and ecosystem services. Filling this knowledge gap is becoming increasingly important as the extent of macroalgal habitat may change according to climate-related coral mortality and regime shifts.

\section{ACKNOWLEDGEMENTS}

We thank participants to our special session on tropical macroalgal fishes at the 2017 Australian Society for Fish Biology Conference and 10th Indo-Pacific Fish Conference for helpful discussions in the early phase of this project. Support was provided by The Australian National University (National Institutes Grant-Research School of Biology), WA Department of Biodiversity, Conservation \& Attractions, Australian Institute of Marine Science, the Environment Conservation Fund of the Government of Hong Kong SAR (ECF15/2015 to PTYL and PKSL), the Philippine Department of Science and Technology Grants-in-Aid Program (to RAA and AAB), the Australian Research Council (DE130100688 to ASH), the Royal Society (UF140691 fellowship to NAJG), and the Swedish Research Council (2015-01257, E0344801). We thank Sofia Wikström and three anonymous peer reviewers for constructive comments on earlier drafts.

\section{DATA AVAILABILITY STATEMENT}

Metadata used in the analyses are provided in online Supporting Information.

\section{ORCID}

Christopher J. Fulton (iD https://orcid.org/0000-0002-1140-1999

Charlotte Berkström iD https://orcid.org/0000-0002-7900-4754

Shaun K. Wilson (iD https://orcid.org/0000-0002-4590-0948

Rene A. Abesamis (iD https://orcid.org/0000-0001-7456-1415

Michael Bradley (iD https://orcid.org/0000-0002-0824-6414

Martial Depczynski iD https://orcid.org/0000-0001-8723-0076

Nicholas A. J. Graham iD https://orcid.org/0000-0002-0304-7467

Michel Kulbicki iD https://orcid.org/0000-0003-1258-5061

Paloma A. Matis iD https://orcid.org/0000-0003-3675-3576

\section{REFERENCES}

Aburto-Oropeza, O., Sala, E., Paredes, G., Mendoza, A., \& Ballesteros, E. (2007). Predictability of reef fish recruitment in a highly variable nursery habitat. Ecology, 88, 2220-2228.

Adams, A. J., Dahlgren, C. P., Kellison, G. T., Kendall, M. S., Layman, C. A., Ley, J. A., ... Serafy, J. E. (2006). Nursery function of tropical backreef systems. Marine Ecology Progress Series, 318, 287-301.

Beck, M. W., Heck, K. L., Able, K. W., Childers, D. L., Eggleston, D. B., Gillanders, B. M., ... Weinstein, M. P. (2001). The identification, conservation, and management of estuarine and marine nurseries for fish and invertebrates. BioScience, 51, 633-641. 
Bell, J. D., Ganachaud, A., Gehrke, P. C., Griffiths, S. P., Hobday, A. J., Hoegh-Guldberg, O., ... Waycott, M. (2013). Mixed responses of tropical Pacific fisheries and aquaculture to climate change. Nature Climate Change, 3, 591-599. https://doi.org/10.1038/nclimate1838

Berkström, C., Gullström, M., Lindborg, R., Mwandya, A. W., Yahya, S. A. S., Kautsky, N., \& Nyström, M. (2012). Exploring 'knowns' and 'unknowns' in tropical seascape connectivity with insights from East African coral reefs. Estuarine, Coastal and Shelf Science, 107, 1-21. https://doi.org/10.1016/j.ecss.2012.03.020

Berkström, C., Lindborg, R., Thyresson, M., \& Gullström, M. (2013). Assessing connectivity in a tropical embayment: Fish migrations and seascape ecology. Biological Conservation, 166, 43-53. https://doi. org/10.1016/j.biocon.2013.06.013

Bertocci, I., Araújo, R., Oliveira, P., \& Sousa-Pinto, I. (2015). Potential effects of kelp species on local fisheries. Journal of Applied Ecology, 52, 1216-1226. https://doi.org/10.1111/1365-2664.12483

Bijoux, J. P., Dagorn, L., Berke, G., Cowley, P. D., Soria, M., Gaertner, J.C., \& Robinson, J. (2013). Temporal dynamics, residency and site fidelity of spawning aggregations of a herbivorous tropical reef fish Siganus sutor. Marine Ecology Progress Series, 475, 233-247. https:// doi.org/10.1007/s00338-013-1075-4

Bittick, S. J., Clausing, R. J., Fong, C. R., Scoma, S. R., \& Fong, P. (2019). A rapidly expanding macroalga acts as a foundational species providing trophic support and habitat in the South Pacific. Ecosystems, 22, 165-173. https://doi.org/10.1007/s10021-018-0261-1

Bradley, M., Baker, R., Nagelkerken, I., \& Sheaves, M. (2019). Context is more important than habitat type in determining use by juvenile fish. Landscape Ecology, 34, 427-442. https://doi.org/10.1007/s1098 0-019-00781-3

Brandl, S. J., Tornabene, L., Goatley, C. H. R., Casey, J. M., Morais, R. A., Côté, I. M., ... Bellwood, D. R. (2019). Demographic dynamics of the smallest marine vertebrates fuel coral-reef ecosystem functioning. Science, 364, 1189-1192. https://doi.org/10.1038/45533

Brown, C. J., Broadley, A., Adame, F., Branch, T. A., Turschwell, M. P., \& Connolly, R. M. (2018). The assessment of fishery status depends on the condition of fish habitats. Fish and Fisheries, 20, 1-14. https://doi. org $/ 10.1111 /$ faf.12318

Burke, L., Reytar, K., Spalding, M., \& Perry, A. (2012). Reefs at risk revisited in the coral triangle. Washington: World Resources Institute.

Cabral, R. B., \& Geronimo, R. C. (2018). How important are coral reefs to food security in the Philippines? Diving deeper than national aggregates and averages. Marine Policy, 91, 136-141. https://doi. org/10.1016/j.marpol.2018.02.007

Campos, W. L., del Norte-Campos, C., \& McManus, J. W. (1994). Yield estimates, catch, effort and fishery potential of the reef flat in Cape Bolinao, Philippines. Journal of Applied Ichthyology, 10, 82-95.

Chaves, L. T. C., Pereira, P. H. C., \& Feitosa, J. L. L. (2013). Coral reef fish association with macroalgal beds on a tropical reef system in Northeastern Brazil. Marine and Freshwater Research, 64, 1101-1111. https://doi.org/10.1071/MF13054

Coker, D. J., Wilson, S. K., \& Pratchett, M. S. (2014). Importance of live coral habitat for reef fishes. Reviews in Fish Biology and Fisheries, 24, 89-126. https://doi.org/10.1007/s11160-013-9319-5

Cumming, G. S. (2011). Spatial resilience: Integrating landscape ecology, resilience, and sustainability. Landscape Ecology, 26, 899-909. https://doi.org/10.1007/s10980-011-9623-1

Dahlgren, C. P., \& Eggleston, D. B. (2000). Ecological processes underlying ontogenetic habitat shifts in a coral reef fish. Ecology, 81, 2227-2240.

Dahlgren, C. P., Kellison, G. T., Adams, A. J., Gillanders, B. M., Kendall, M. S., Layman, C. A., ... Serafy, J. E. (2006). Marine nurseries and effective juvenile habitats: Concepts and applications. Marine Ecology Progress Series, 312, 291-295.

Depczynski, M., Fulton, C. J., Marnane, M. J., \& Bellwood, D. R. (2007). Life history patterns shape energy allocation among fishes on coral reefs. Oecologia, 153, 111-120. https://doi.org/10.1007/s0044 2-007-0714-2

Diaz-Pulido, G., McCook, L. J., Larkum, A. W., Lotze, H. K., Raven, J. A., Schaffelke, B., ... Steneck, R. S. (2007). Vulnerability of macroalgae of the Great Barrier Reef to climate change. In P. A. Marshall, \& J. Johnson (Eds.), Climate change and the Great Barrier Reef: A vulnerability assessment (pp. 153-192). Townsville: Great Barrier Reef Marine Park Authority.

Edgar, G. J., \& Aoki, M. (1993). Resource limitation and fish predation: Their importance to mobile epifauna associated with Japanese Sargassum. Oecologia, 95, 122-133.

Eggertsen, L., Ferreira, C. E. L., Fontoura, L., Kautsky, N., Gullström, M., \& Berkström, C. (2017). Seaweed beds support more juvenile reef fish than seagrass beds in a south-western Atlantic tropical seascape. Estuarine, Coastal and Shelf Science, 196, 97-108. https://doi. org/10.1016/j.ecss.2017.06.041

Eggertsen, M., Chacin, D. H., Åkerlund, C., Halling, C., \& Berkström, C. (2019). Contrasting distribution and foraging patterns of herbivorous and detritivorous fishes across multiple habitats in a tropical seascape. Marine Biology, 166, 51. https://doi.org/10.1007/s0022 7-019-3498-0

Eggleston, D. (1995). Recruitment in Nassau grouper Epinephelus striatus: Post-settlement abundance, microhabitat features, and ontogenetic habitat shifts. Marine Ecology Progress Series, 124, 9-22.

Evans, R. D., Wilson, S. K., Field, S. N., \& Moore, J. A. Y. (2014). Importance of macroalgal fields as coral reef fish nursery habitat in north-west Australia. Marine Biology, 161, 599-607. https://doi.org/10.1007/ s00227-013-2362-x

Fairclough, D. V., \& Nakazono, A. (2004). Choerodon schoenleinii. IUCN 2007. 2007 IUCN Red List of Threatened Species.

FAO. (2018). Fishery and Aquaculture Statistics. Global capture production 1950-2016 (FishstatJ). Retrieved from http://www.fao.org/fishery/ statistics/software/fishstatj/en.

Faunce, C. H., \& Serafy, J. E. (2006). Mangroves as fish habitat: 50 years of field studies. Marine Ecology Progress Series, 318, 1-18.

Feary, D. A., Almany, G. R., McCormick, M. I., \& Jones, G. P. (2007). Habitat choice, recruitment and the response of coral reef fishes to coral degradation. Oecologia, 153, 727-737. https://doi.org/10.1007/ s00442-007-0773-4

Fox, R. J., \& Bellwood, D. R. (2008). Remote video bioassays reveal the potential feeding impact of the rabbitfish Siganus canaliculatus (f: Siganidae) on an inner-shelf reef of the Great Barrier Reef. Coral Reefs, 27, 605-615. https://doi.org/10.1007/s00338-008-0359-6

Froese, R. \& Pauly, D. (2018). FishBase (version 06s/2018). Retrieved from http://www.fishbase.org

Fulton, C. J., Abesamis, R. A., Berkström, C., Depczynski, M., Graham, N. A. J., Holmes, T. H., ... Wilson, S. K. (2019). Form and function of tropical macroalgal reefs in the Anthropocene. Functional Ecology, 33, 989-999. https://doi.org/10.1111/1365-2435.13282

Gillanders, B. M. (2006). Seagrasses, fish, and fisheries. In A. W. Larkum, R. J. Orth, \& C. M. Duarte (Eds.), Seagrasses: Biology, ecology and conservation (pp. 503-536). The Netherlands: Springer.

Gillanders, B. M., Able, K. W., Brown, J. A., Eggleston, D. B., \& Sheridan, P. F. (2003). Evidence of connectivity between juvenile and adult habitats for mobile marine fauna: An important component of nurseries. Marine Ecology Progress Series, 247, 281-295.

Graham, N. A. J., Jennings, S., MacNeil, M. A., Mouillot, D., \& Wilson, S. K. (2015). Predicting climate-driven regime shifts versus rebound potential in coral reefs. Nature, 518, 94-97. https://doi.org/10.1038/ nature14140

Graham, N. A. J., \& Nash, K. L. (2013). The importance of structural complexity in coral reef ecosystems. Coral Reefs, 32, 315-326. https:// doi.org/10.1007/s00338-012-0984-y

Graham, N. A. J., Wilson, S. K., Jennings, S., Polunin, N. V., Bijoux, J. P., \& Robinson, J. (2006). Dynamic fragility of oceanic coral reef 
ecosystems. Proceedings of the National Academy of Sciences, 103, 8425-8429. https://doi.org/10.1073/pnas.0600693103

Graham, N. A. J., Wilson, S. K., Jennings, S., Polunin, N. V. C., Robinson, J., Bijoux, J. P., \& Daw, T. M. (2007). Lag effects in the impacts of mass coral bleaching on coral reef fish, fisheries and ecosystems. Conservation Biology, 21, 1291-1300. https://doi. org/10.1111/j.1523-1739.2007.00754.x

Green, A. L., Fernandes, L., Almany, G., Abesamis, R., McLeod, E., Aliño, P. M., ... Pressey, R. L. (2014). Designing marine reserves for fisheries management, biodiversity conservation, and climate change adaptation. Coastal Management, 42, 143-159. https://doi. org/10.1080/08920753.2014.877763

Hale, R., \& Swearer, S. E. (2016). Ecological traps: Current evidence and future directions. Proceedings of the Royal Society $B$ : Biological Sciences, 283(1824), 494-499. https://doi.org/10.1098/ rspb.2015.2647

Hale, R., Treml, E. A., \& Swearer, S. E. (2015). Evaluating the metapopulation consequences of ecological traps. Proceedings of the Royal Society B: Biological Sciences, 282(1804), 20142930. https://doi. org/10.1098/rspb.2014.2930

Hehre, E. J., \& Meeuwig, J. J. (2016). A global analysis of the relationship between farmed seaweed production and herbivorous fish catch. PLoS ONE, 11, e0148250. https://doi.org/10.1371/journ al.pone. 0148250

Hempson, T. N., Graham, N. A., MacNeil, M. A., Bodin, N., \& Wilson, S. K. (2018). Regime shifts shorten food chains for mesopredators with potential sublethal effects. Functional Ecology, 32, 820-830. https:// doi.org/10.1111/1365-2435.13012

Hempson, T. N., Graham, N. A. J., MacNeil, M. A., Hoey, A. S., \& Wilson, S. K. (2018). Ecosystem regime shifts disrupt trophic structure. Ecological Applications, 28, 191-200. https://doi.org/10.1111/ ijlh.12426

Hicks, C. C., \& McClanahan, T. R. (2012). Assessing gear modifications needed to optimize yields in a heavily exploited, multi-species, seagrass and coral reef fishery. PLoS ONE, 7, e36022. https://doi. org/10.1371/journal.pone.0036022

Hoey, A. S., \& Bellwood, D. R. (2011). Suppression of herbivory by macroalgal density: A critical feedback on coral reefs? Ecology Letters, 14, 267-273. https://doi.org/10.1111/j.1461-0248.2010.01581.x

Hoey, A. S., Brandl, S. J., \& Bellwood, D. R. (2013). Diet and cross-shelf distribution of rabbitfishes (f. Siganidae) on the northern Great Barrier Reef: Implications for ecosystem function. Coral Reefs, 32, 973-984. https://doi.org/10.1007/s00338-013-1043-z

Holmes, T. H., Wilson, S. K., Vanderklift, M., Babcock, R., \& Fraser, M. (2012). The role of Thalassoma lunare as a predator of juvenile fish on a sub-tropical coral reef. Coral Reefs, 31, 1113-1123. https://doi. org/10.1007/s00338-012-0934-8

Horinouchi, M. (2007). Review of the effects of within-patch scale structural complexity on seagrass fishes. Journal of Experimental Marine Biology \& Ecology, 350, 111-129. https://doi.org/10.1016/j. jembe.2007.06.015

Hsu, T.-H., Adiputra, Y. T., Burridge, C. P., \& Gwo, J.-C. (2011). Two spinefoot colour morphs: Mottled spinefoot Siganus fuscescens and white-spotted spinefoot Siganus canaliculatus are synonyms. Journal of Fish Biology, 79, 1350-1355. https://doi. org/10.1111/j.1095-8649.2011.03104.x

Jumawan-Nanual, B., \& Metillo, E. B. (2008). Population structure and reproductive biology of Siganus fuscescens Houttuyn 1782 (Perciformes, Siganidae) in Pujada Bay, Southeastern Mindanao, Philippines. Philippine Scientist, 45, 62-79. https://doi.org/10.3860/ psci.v45i0.992

Lim, I. E., Wilson, S. K., Holmes, T. H., Noble, M. M., \& Fulton, C. J. (2016). Specialization within a shifting habitat mosaic underpins the seasonal abundance of a tropical fish. Ecosphere, 7, e01212. https://doi. org/10.1002/ecs2.1212
Loffler, Z., \& Hoey, A. S. (2018). Canopy-forming macroalgal beds (Sargassum) on coral reefs are resilient to physical disturbance. Journal of Ecology, 106, 1156-1164. https://doi. org/10.1111/1365-2745.12875

MacNeil, M. A., Graham, N. A. J., Cinner, J. E., Dulvy, N. K., Loring, P. A., Jennings, S., ... McClanahan, T. R. (2010). Transitional states in marine fisheries: Adapting to predicted global change. Philosophical Transactions of the Royal Society B, 365, 3753-3763. https://doi. org/10.1098/rstb.2010.0289

Martin, T. S. H., Olds, A. D., Olalde, A. B. H., Berkström, C., Gilby, B. L., Schlacher, T. A., ... Connolly, R. M. (2018). Habitat proximity exerts opposing effects on key ecological functions. Landscape Ecology, 33, 1273-1286. https://doi.org/10.1007/s10980-018-0680-6

Martin-Smith, K. M. (1993). Abundance of mobile epifauna: The role of habitat complexity and predation by fishes. Journal of Experimental Marine Biology \& Ecology, 174, 243-260.

McClanahan, T. R. (2006). Challenges and accomplishments towards sustainable reef fisheries. In I. M. Côté, \& J. D. Reynolds (Eds.), Coral reef conservation (pp. 147-182). Cambridge: Cambridge University Press.

McClanahan, T. R., Hendrick, V., Rodrigues, M. J., \& Polunin, N. V. C. (1999). Varying responses of herbivorous and invertebrate-feeding fishes to macroalgal reduction on a coral reef. Coral Reefs, 18, 195-203.

McClanahan, T. R., Hicks, C. C., \& Darling, E. S. (2008). Malthusian overfishing and efforts to overcome it on Kenyan coral reefs. Ecological Applications, 18, 1516-1529. https://doi.org/10.1890/07-0876.1

McCourt, R. M. (1984). Seasonal patterns of abundance, distributions, and phenology in relation to growth strategies of three Sargassum species. Journal of Experimental Marine Biology \& Ecology, 74, 141-156.

McManus, J. W., Nañola, C. L. Jr, Reyes, R. B. Jr, \& Kesner, K. N. (1992). Resource ecology of the Bolinao coral reef system. ICLARM Studies Review, 22, 117.

Mellin, C., Kulbicki, M., \& Ponton, D. (2007). Seasonal and ontogenetic patterns of habitat use in coral reef fish juveniles. Estuarine, Coastal and Shelf Science, 75, 481-491. https://doi.org/10.1016/j. ecss.2007.05.026

Morais, R. A., \& Bellwood, D. R. (2018). Global drivers of reef fish growth. Fish and Fisheries, 19, 874-889. https://doi.org/10.1111/faf.12297

Murphy, H. M., \& Jenkins, G. P. (2010). Observational methods used in marine spatial monitoring of fishes and associated habitats: A review. Marine and Freshwater Research, 61, 236-252. https://doi. org/10.1071/MF09068

Nagelkerken, I., Sheaves, M., Baker, R., \& Connolly, R. M. (2015). The seascape nursery: A novel spatial approach to identify and manage nurseries for coastal marine fauna. Fish and Fisheries, 16, 362-371. https://doi.org/10.1111/faf.12057

Newton, K., Côté, I. M., Pilling, G. M., Jennings, S., \& Dulvy, N. K. (2007). Current and future sustainability of island coral reef fisheries. Current Biology, 17, 655-658. https://doi.org/10.1016/j. cub.2007.02.054

Olds, A. D., Nagelkerken, I., Huijbers, C. M., Gilby, B. L., Pittman, S. J., \& Schlacher, T. A. (2018). Connectivity in coastal seascapes. In S. J. Pittman (Ed.), Seascape ecology. London: John Wiley \& Sons.

Olsen, Y. S., Mattio, L., Zavala Perez, A., Babcock, R. C., Thompson, D., Haywood, M. D., ... Kendrick, G. A. (2019). Drivers of species richness and abundance of marine macrophytes on shallow tropical reefs of north-western Australia. Journal of Biogeography, 46, 170-184. https://doi.org/10.1111/jbi.13470

Ornellas, A. B., \& Coutinho, R. (1998). Spatial and temporal patterns of distribution and abundance of a tropical fish assemblage in a seasonal Sargassum bed, Cabo Frio Island, Brazil. Journal of Fish Biology, 53(Supplement, A), 198-208.

Pauly, D., \& Zeller, D. (2016). Catch reconstructions reveal that global marine fisheries catches are higher than reported and declining. Nature Communications, 7, 10244. https://doi.org/10.1038/ncomms10244 
Pérez-Matus, A., Sánchez, F., González-But, J., \& Lamb, R. (2016). Understory algae associations and predation risk influence broadscale kelp habitat use in a temperate reef fish. Marine Ecology Progress Series, 559, 147-158. https://doi.org/10.3354/meps11892

Pratchett, M. S., Hoey, A. S., \& Wilson, S. K. (2014). Reef degradation and the loss of critical ecosystem goods and services provided by coral reef fishes. Current Opinion in Environmental Sustainability, 7, 37-43. https://doi.org/10.1016/j.cosust.2013.11.022

Pratchett, M. S., Munday, P. L., Wilson, S. K., Graham, N. A. J., Cinner, J. E., Bellwood, D. R., ... McClanahan, T. R. (2008). Effects of climate-induced coral bleaching on coral-reef fishes - Ecological and economic consequences. Oceanography and Marine Biology: An Annual Review, 46, 251-296. https://doi.org/10.1201/9781420065 756.ch6

Robinson, J., Graham, N. A. J., Grüss, A., Gerry, C., \& Bijoux, J. (2017). Fishery benefits from exploiting spawning aggregations not solely dependent on enhanced fish density. African Journal of Marine Science, 39, 269-278. https://doi.org/10.2989/18142 32X.2017.1364665

Robinson, J., Samoilys, M. A., Grandcourt, E., Julie, D., Cedras, M. \& Gerry, C. (2011). The importance of targeted spawning aggregation fishing to the management of Seychelle's trap fishery. Fisheries Research, 112, 96-103. https://doi.org/10.1016/j.fishr es.2011.08.015

Robinson, J. P. W., Wilson, S. K., Robinson, J., Gerry, C., Lucas, J., Assan, C., ... Graham, N. A. J. (2018). Productive instability of coral reef fisheries after climate-driven regime shifts. Nature Ecology and Evolution, 3, 183-190. https://doi.org/10.1038/s4155 9-018-0715-z

Rodewald, A. D., Shustack, D. P., \& Hitchcock, L. E. (2010). Exotic shrubs as ephemeral ecological traps for nesting birds. Biological Invasions, 12, 33. https://doi.org/10.1007/s10530-009-9426-3

Rogers, R. W. (1997). Brown algae on Heron reef flat, Great Barrier Reef, Australia: Spatial, seasonal and secular variation in cover. Botanica Marina, 40, 113-118.

Rossier, O., \& Kulbicki, M. (2000). A comparison of fish assemblages from two types of algal beds and coral reefs in the south-west lagoon of New Caledonia. Cybium, 24, 3-26.

Ryan, K. L., Hall, N. G., Lai, E. K., Smallwood, C. B., Taylor, S. M., \& Wise, B. S. (2017). Statewide survey of boat-based recreational fishing in Western Australia 2015/16. Perth: Government of Western Australia Fisheries Research Division.

Sambrook, K., Hoey, A. S., Andréfouët, S., Cumming, G. S., Duce, S., \& Bonin, M. C. (2019). Beyond the reef: The widespread use of nonreef habitats by coral reef fishes. Fish and Fisheries, 20, 903-920. https://doi.org/10.1111/faf.12383

Schaffelke, B., \& Klumpp, D. W. (1998). Nutrient-limited growth of the coral reef macroalga Sargassum baccularia and experimental growth enhancement by nutrient addition in continuous flow culture. Marine Ecology Progress Series, 164, 199-211.

Sih, A., Ferrari, M. C. O., \& Harris, D. J. (2011). Evolution and behavioural responses to human-induced rapid environmental change. Evolutionary Applications, 4, 367-387. https://doi. org/10.1111/j.1752-4571.2010.00166.x

Smallwood, C. B., Beckley, L. E., \& Moore, S. A. (2013). Effects of adjacent land tenure on visitor use of Ningaloo Marine Park, Western Australia. Australasian Journal of Environmental Management, 20, 130-146. https://doi.org/10.1080/14486563.2013.787910

Soliman, V. S., \& Yamaoka, K. (2010). Assessment of the fishery of siganid juveniles caught by bagnet in Lagonoy Gulf, Southeastern Luzon, Philippines. Journal of Applied Ichthyology, 26, 561-567. https://doi. org/10.1111/j.1439-0426.2010.01477.x

Stimson, J. (2013). Consumption by herbivorous fishes of macroalgae exported from coral reef flat refuges to the reef slope. Marine
Ecology Progress Series, 472, 87-99. https://doi.org/10.3354/meps1 0020

Tano, S., Eggertsen, M., Wikström, S. A., Berkström, C., Buriyo, A. S., \& Halling, C. (2016). Tropical seaweed beds are important habitats for mobile invertebrate epifauna. Estuarine, Coastal and Shelf Science, 183, 1-12. https://doi.org/10.1016/j.ecss.2016.10.010

Tano, S., Eggertsen, M., Wikström, S. A., Berkström, C., Buriyo, A. S., \& Halling, C. (2017). Tropical seaweed beds as important habitats for juvenile fish. Marine and Freshwater Research, 68, 1921-1934. https:// doi.org/10.1071/MF16153

Umar, M. J., McCook, L. J., \& Price, I. R. (1998). Effects of sediment deposition on the seaweed Sargassum on a fringing coral reef. Coral Reefs, 17, 169-177.

Unsworth, R. K. F., Taylor, J. D., Powell, A., Bell, J. J., \& Smith, D. J. (2007). The contribution of scarid herbivory to seagrass ecosystem dynamics in the Indo-Pacific. Estuarine, Coastal and Shelf Science, 74, 53-62. https://doi.org/10.1016/j.ecss.2007.04.001

van Lier, J. R., Wilson, S. K., Depczynski, M., Wenger, L. N., \& Fulton, C. J. (2018). Habitat connectivity and complexity underpin fish community structure across a seascape of tropical macroalgae meadows. Landscape Ecology, 33, 1287-1300. https://doi.org/10.1007/s1098 0-018-0682-4

Vázquez, D. P., \& Simberloff, D. (2002). Ecological specialization and susceptibility to disturbance: Conjectures and refutations. American Naturalist, 159, 606-623.

Weldon, A. J., \& Haddad, N. M. (2005). The effects of patch shape on indigo buntings: Evidence for an ecological trap. Ecology, 86, 1422-1431.

Wenger, L. N., Van Lier, J. R., \& Fulton, C. J. (2018). Microhabitat selectivity shapes the seascape ecology of a carnivorous macroalgae-associated tropical fish. Marine Ecology Progress Series, 590, 187-200. https://doi.org/10.3354/meps12473

Whitfield, A. K. (2017). The role of seagrass meadows, mangrove forests, salt marshes and reed beds as nursery areas and food sources for fishes in estuaries. Reviews in Fish Biology and Fisheries, 27, 75-110. https://doi.org/10.1007/s11160-016-9454-x

Wilson, S. K., Bellwood, D. R., Choat, J. H., \& Furnas, M. J. (2003). Detritus in the epilithic algal matrix and its use by coral reef fishes. Oceanography and Marine Biology: Annual Review, 41, 279-310.

Wilson, S. K., Depcyznski, M., Fisher, R., Holmes, T. H., Noble, M. M., Radford, B. T., ... Fulton, C. J. (2018). Climatic forcing and larval dispersal capabilities shape the replenishment of fishes and their habitat-forming biota on a tropical coral reef. Ecology and Evolution, 8, 1918-1928. https://doi.org/10.1002/ece3.3779

Wilson, S. K., Depczynski, M., Fisher, R., Holmes, T. H., O'Leary, R. A., \& Tinkler, P. (2010). Habitat associations of juvenile fish at Ningaloo reef, Western Australia: The importance of coral and algae. PLoS ONE, 5, e15185. https://doi.org/10.1371/journal.pone.0015185

Wilson, S. K., Depczynski, M., Holmes, T. H., Noble, M. M., Radford, B. T., Tinkler, P., \& Fulton, C. J. (2017). Climatic conditions and nursery habitat quality provide indicators of reef fish recruitment strength. Limnology and Oceanography, 62, 1868-1880. https://doi. org/10.1002/Ino.10540

Wilson, S. K., Fulton, C. J., Depczynski, M., Holmes, T. H., Noble, M. M., Radford, B., \& Tinkler, P. (2014). Seasonal changes in habitat structure underpin shifts in macroalgae-associated tropical fish communities. Marine Biology, 161, 2597-2607. https://doi.org/10.1007/s0022 7-014-2531-6

Wilson, S. K., Graham, N. A. J., Pratchett, M. S., Jones, G. P., \& Polunin, N. V. C. (2006). Multiple disturbances and the global degradation of coral reefs: Are reef fishes at risk or resilient? Global Change Biology, 12, 2220-2234. https://doi.org/10.1111/j.1365-2486.2006.01252.x

Zubia, M., Andréfouët, S., \& Payri, C. (2015). Distribution and biomass evaluation of drifting brown algae from Moorea lagoon (French Polynesia) 
for eco-friendly agricultural use. Journal of Applied Phycology, 27, 1277-1287. https://doi.org/10.1007/s10811-014-0400-9

\section{SUPPORTING INFORMATION}

Additional supporting information may be found online in the Supporting Information section.
How to cite this article: Fulton CJ, Berkström C, Wilson SK, et al. Macroalgal meadow habitats support fish and fisheries in diverse tropical seascapes. Fish Fish. 2020;00:1-18.

https://doi.org/10.1111/faf.12455 